University of South Florida

DIGITAL COMMONS

@ UNIVERSITY OF SOUTH FLORIDA
Digital Commons @ University of

South Florida

$4-1-2001$

\title{
Update of FDOT State Park \& Ride Lot Program Planning Manual
}

CUTR

Follow this and additional works at: https://digitalcommons.usf.edu/cutr_nctr

\section{Scholar Commons Citation}

CUTR, "Update of FDOT State Park \& Ride Lot Program Planning Manual" (2001). Research Reports. 191.

https://digitalcommons.usf.edu/cutr_nctr/191

This Technical Report is brought to you for free and open access by the National Center for Transit Research (NCTR) Archive (2000-2020) at Digital Commons @ University of South Florida. It has been accepted for inclusion in Research Reports by an authorized administrator of Digital Commons @ University of South Florida. For more information, please contact digitalcommons@usf.edu. 


\title{
UPDATE OF FDOT STATE PARK \& RIDE LOT PROGRAM PLANNING MANUAL
}

Chapters 3, 4, and 6

\author{
Principal Investigators: \\ Xuehao Chu \\ Laurel Land \\ Ram Pendyala \\ Center for Urban Transportation Research \\ University of South Florida
}

April 2001 


\section{CHAPTER 3: SITE SELECTION}

The process of selecting sites for park-and-ride facilities is two-fold. First, it is necessary to identify general areas that may be able to support one or more park-and-ride facilities. Using standards for lot types will assist in determining feasibility of the area. Second, specific sites within the identified area are selected and their merits are assessed. This chapter describes criteria for siting and sets forth standards for evaluating park-and-ride facilities.

\section{AREA IDENTIFICATION}

The first step in the site selection process is to identify areas where park-and-ride may be feasible. This is largely a common-sense approach, based on existing conditions, such as:

- informal park-and-ride activity

- density of residential areas

- intensity and concentration of employment

- distance between major residential areas and employment centers

- current and future levels of service on pertinent roadways.

Additionally, area identification is dependent upon the facility type. Table 3-1 presents criteria and standards for identifying potential areas for park-and-ride facilities.

Table 3-1

Identifying Areas for Park and Ride Facilities

\begin{tabular}{|c|c|c|}
\hline Lot Type & Criteria & Standards \\
\hline $\begin{array}{l}\text { Urban } \\
\text { Corridor } \\
\text { (page 2) }\end{array}$ & $\begin{array}{l}\text { Corridor level-of-service } \\
\text { Corridor traffic } \\
\text { Service area dwelling units } \\
\text { Distance from employment center }\end{array}$ & $\begin{array}{l}\text { Level-of-Service } E \text { or worse } \\
50,000 \text { ADT (based on } 100 \text {-space facility) } \\
>2,000 \text { dwelling units within } 2 \text { miles of lot [1] } \\
>10 \text { miles [1] }\end{array}$ \\
\hline $\begin{array}{l}\text { HOV Corridor } \\
\text { (page 2) }\end{array}$ & $\begin{array}{l}\text { Traffic on feeder route to HOV facility } \\
\text { Feeder road system configuration } \\
\text { Lot spacing }\end{array}$ & $\begin{array}{l}\text { High volumes, }>35,000 \text { ADT } \\
\text { Confluence of feeder roads near facility } \\
5-10 \text { miles minimum }\end{array}$ \\
\hline $\begin{array}{l}\text { Peripheral } \\
\text { (page 3) }\end{array}$ & $\begin{array}{l}\text { Parking demand/supply } \\
\text { Activity center circulation } \\
\text { Activity center access route } \\
\text { Existing parking facilities }\end{array}$ & $\begin{array}{l}>1.0 \\
\text { Congested or restricted access } \\
\text { Major access route } \\
\text { Insufficient in area }\end{array}$ \\
\hline $\begin{array}{l}\text { Urban Fringe } \\
\text { (page 3) }\end{array}$ & $\begin{array}{l}\text { Access corridor to urban area } \\
\text { Employment concentrations } \\
\text { Location within urban area } \\
\text { Vicinity of shopping centers }\end{array}$ & $\begin{array}{l}\text { Arterial with } 4 \text { lanes or greater } \\
>10,000 \text { employees per employment center } \\
\text { Vicinity of urban area boundary } \\
>3 / 4 \text { mile from commute route }\end{array}$ \\
\hline $\begin{array}{l}\text { Remote } \\
\text { (page 4) }\end{array}$ & $\begin{array}{l}\text { Orientation to urban area } \\
\text { Urban employment } \\
\text { Orientation to service area population } \\
\text { Available right-of-way } \\
\text { Commute route }\end{array}$ & $\begin{array}{l}\text { Between } 20 \text { and } 60 \text { miles from employment centers } \\
>20,000 \text { employees } \\
\text { Centrally located } \\
\text { Publicly-owned right-of-way available } \\
<1 \text { mile from commute route }\end{array}$ \\
\hline
\end{tabular}




\section{Urban Corridor Lots}

These lots are located along a major commute corridor within an urban area and are served by HOV lanes or line-haul transit consisting of express bus, urban rail, or commuter rail services. Trip origin patterns tend to be dispersed along the corridor; trip destination patterns are usually concentrated in a central business district or other major employment center.

\begin{tabular}{|l|l|}
\hline Corridor level-of-service & Level-of-Service E or worse \\
Corridor traffic & 50,000 ADT (based on 100-space facility) \\
Service area dwelling units & $>2,000$ dwelling units within 2 miles of lot [1] \\
Distance from employment center & $>10$ miles [1] \\
\hline
\end{tabular}

The four criteria illustrated in Table 3-1 (reiterated above) reflect primary factors that influence lot demand. The first two assist in identifying corridors likely to support park-and-ride; the last two help to identify locations within the corridor that are best suited for park-and-ride development. These are based on the premise that it is better to locate a lot closer to trip origins (residential areas) and further from trip destinations (employment centers).

Corridors operating at Level of Service (LOS) E or worse are ideal for park-and-ride development. Future year Level of Service is also important, since it can be used to identify corridors with the highest potential for park-and-ride usage. Of two corridors operating at LOS E, the one with the highest design year ADT will be more attractive for park-and-ride development. Corridor traffic of 50,000 ADT is suggested as a minimum standard.

The effective Long-Range Transportation Plan documentation or urban model output can also assist in identifying appropriate corridors for park-and-ride facilities. This information is maintained by the local Metropolitan Planning Organization and/or Florida Department of Transportation District Planning Office.

\section{HOV Corridor Lots}

HOV corridor lots are a subset of the urban corridor lots, and are located adjacent to major commuting highways with HOV lanes. They are located and sized to maximize usage of HOV lanes, and support carpooling and access to line-haul transit that uses the HOV lanes. Trip origins tend to be dispersed along the corridor. Trip destinations are usually concentrated in a central business district or major employment center.

HOV facility design may include a number of park-and-ride lots in the corridor in order to maximize usage. Therefore, lot spacing and its effect on usage must be taken into account. Parkers tend to use the first lot encountered along their travel path. If lots are too closely spaced, they may be underutilized.

\begin{tabular}{|l|l|}
\hline $\begin{array}{l}\text { Traffic on feeder route to HOV facility } \\
\text { Feeder road system configuration }\end{array}$ & $\begin{array}{l}\text { High volumes, }>35,000 \text { ADT } \\
\text { Confluence of feeder roads near facility } \\
\text { Lot spacing }\end{array}$ \\
$5-10$ miles minimum
\end{tabular}


Sites should be located adjacent to the HOV facility on an access route that carries a significant number of vehicles accessing the highway containing the HOV lanes. 35,000 ADT is suggested as a working minimum amount of traffic. This minimum ADT value should increase as lot spacing decreases.

If possible, a park-and-ride facility should be located at the confluence of a number of access routes. Such a location experiences a significant amount of traffic, thereby increasing the propensity to use the facility. The most highly used park-and-ride lot in Florida - Golden Glades in Dade County - is located at the junction of five major commuting highways, which carried in excess of 370,000 vehicles per day in 1989.

\section{Peripheral Lots}

These facilities serve activity centers having limited parking and/or auto access, such as auto-free zones and colleges. As such, they are usually located at the outer edge of activity centers. Distances to the lot from residential areas are typically longer than other park-and-ride facilities, while distances from the lot to the activity center are usually shorter.

\begin{tabular}{|l|l|}
\hline Parking demand/supply & $>1.0$ \\
Activity center circulation & Congested or restricted access \\
Activity center access route & Major access route \\
Existing parking facilities & Insufficient in area \\
\hline
\end{tabular}

Four criteria are critical to the location of peripheral lots. The first criterion determines if, in fact, additional parking is needed in the activity center area. If parking is adequate, further evaluation is not warranted, unless other objectives are driving the study such as reducing noise, emissions, and vehicular travel within the activity center. The second touches on these same concerns. Auto accessibility to an activity center may be restricted, either by design or through inadequate street capacity. Such conditions can be used to determine the effectiveness of peripheral parking.

The third and fourth criteria are used to determine feasible locations when additional parking is needed to service an activity center. While supply of parking for an activity center may be inadequate in general, some areas within the center may be adequately served. The fourth criterion suggests that where parking is insufficient, additional parking should be added within that area of the activity center.

\section{Urban Fringe Lot}

Urban fringe lots are located at the outer edge of urban development. Trips tend to originate outside or on the fringe of the urban area, while destinations may be concentrated or dispersed within the urban area. Fringe area lots are generally not served by transit, although this is not universally true.

\begin{tabular}{|l|l|}
\hline Access corridor to urban area & Arterial with 4 lanes or greater \\
Employment concentrations & $>10,000$ employees per employment center \\
Location within urban area & Vicinity of urban area boundary \\
Vicinity of shopping centers & $>3 / 4$ mile from commute route \\
\hline
\end{tabular}

Service area demand and concentrations of employment are factors that determine the usage of an urban fringe lot. Service area demand is reflected in the number of lanes for an adjacent roadway. Employment concentration is also an important consideration for judging the demand for a 
park-and-ride facility. An urban area needs to have a minimum concentration of 10,000 employees per square mile to support the formation of carpools [2]. Shopping center lots are most applicable in fringe areas [3]. The urban fringe will vary, based on the year of the study.

\section{Remote Lots}

Remote lots are generally located outside the urban area in a rural or small town setting. Trip lengths for both home-to-lot and lot-to-work are much longer than for other types of park-and-ride lots.

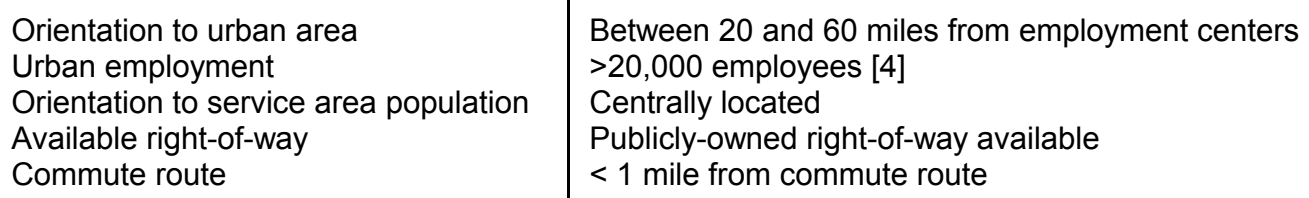

The success of a remote lot is dictated by the amount of employment located at the destination end and the distance traveled [3]. A facility located 60 miles from the employment center is probably the upper limit for usage; 20 miles is suggested as a lower limit. In some metropolitan areas, 20 miles may be considered an urban fringe or corridor lot instead of a remote facility.

The second criteria in the table indicates that more people will travel further, as the urban area employment increases. Carpooling increases with employer size and employment concentration [2, $5,6]$. This is a working minimum employment level. It is provided as a lower limit of employment for consideration of remote lots to service an urban area. When citing remote lots, consideration should also be given to employment concentrations and number of large employers.

Approximately $50 \%$ of remote lot users in Florida live within three miles of the lot and about $90 \%$ come from within 19 miles [3]. This suggests that a remote lot should be centrally located to the service area population. Most remote lots developed in Florida are located in towns.

The last criterion relevant to locating remote park-and-ride lots reflects the fact that lot use will be greater if located near a major commute route oriented towards an urban area. This provides the opportunity to intercept commuters along their normal travel path. Also, such a location provides for better visibility and awareness of the facility.

\section{Plan Incorporation}

Once areas are identified, it is critical to incorporate this information into Long-Range Transportation Plans and/or Comprehensive Plans to provide opportunities for:

- automatic consideration of park-and-ride lots during preliminary phases of road improvement projects, which corresponds to FDOT's policy regarding bike facilities

- developing priority lists in which park-and-ride lots compete for funding with other projects

- assessing impact fees for lot development

- capturing federal funds for facility construction

- developing outlying parking facilities in lieu of downtown parking

- reserving land for future facilities 


\section{SITE IDENTIFICATION}

The second step in the process of site selection is to identify sites with attributes conducive to usage. A poorly located lot will not be used. This step begins with developing an inventory of candidate sites. Properties having existing paved areas that are not used during weekday working hours should be given first consideration. These may include vacant properties, churches, drive-in theaters or civic centers. Florida has made effective use of scarce construction dollars by entering into agreements with local governments and private property owners, and by developing lots on existing Department right-of-way.

The inventory can be produced through contacts with local officials and groups, review of aerial photography, and field reconnaissance. All of these methods should be used in developing the inventory of candidate sites, but at a minimum, field investigations should be performed.

Next, it will be necessary to rate and rank the candidate sites. A set of criteria is first established for use in evaluating each site. A point score is assessed for each evaluation criterion based on a comparison of the site's features against the ideal condition associated with that criterion. All point scores are totaled, with the highest scoring site being the most desirable. The most important factors for consideration are:

Right-of-Way. The level of funding for park-and-ride development has resulted in creative arrangements for land use or donation. Right-of-way costs can often be more than construction costs, particularly when located in densely developed corridors. As a result, this may be the most important factor for determining feasibility.

Atmosphere. For determining the success of a park-and-ride lot, atmosphere may be the most critical factor. This includes safety and environment, both perceived and real. Lots located in areas perceived safe for both the parker and his vehicle are more frequently used. Lots should also be located in areas that are free from annoyances, such as ash emitted from an incinerator or the stench from a landfill.

Site Size. If large enough sites are not available, a number of smaller lots may need to be developed. Sites that are too large result in an over-expenditure of funds, and inefficient use of space. A factor of 300 square feet per stall is typical for surface lots, while 325 square feet per stall is conservative for structures. (See Chapter 4 for further information.)

Visibility. Sites should be visible from adjacent travel routes. Visibility contributes to recognition of an available park-and-ride lot, and is a deterrent to crime. Landscaping should not obscure visibility.

Access. A site must be easily and directly accessible by automobiles and transit vehicles, where transit service is planned. Lots should not divert commuters more than $1 / 2$ to $3 / 4$ mile out of their normal travel path. Access should be safe, with signal control if warranted.

Transit Service. Lot usage increases with transit service. Sites are best located along existing or planned transit routes. 
Access Road Congestion. Congestion between the main travel roadway and the park-and-ride facility can discourage lot usage by adding time to the trip. Sites are best located where time between the main commute roadways and the lot can be minimized.

Transit Design Features. Transit vehicles may not have been considered in the design of the lot. Inadequate turning radii, aisle widths, and pavement design can eliminate a site from further consideration if the site is to serve transit. (See Pedestrian and Transit Friendly Design by Reid Ewing [7]. )

Less important considerations include:

Traffic Circulation. Park-and-ride lots will attract additional traffic to the access roadways. Site selection should minimize congestion on these roadways, particularly if located in residential districts.

Bike Access. Easy access to bicycle routes attracts additional users.

Expansion Potential. Funding constraints may dictate construction of a lost that is smaller than what is needed to meet future demand. In this case, it is important to choose a site with potential for expansion.

A procedure endorsed for use by AASHTO $[8,9]$ is useful for ranking potential sites. The procedure is presented in Appendix E and considers both area and site identification. Point scores for sites under consideration may be quite close [10]. Two adaptations are recommended to remedy this. First, criteria receiving the same score should be eliminated. These will tend to be at the area identification level. For example, it is likely that many sites under consideration will receive the same rating for transit service potential, proximity to major trip generators, user benefits, and orientation to major bottlenecks.

The second adaptation is to assign weighting factors that represent the importance of each criterion to the site selection. For example, land acquisition and land cost may be more critical than site visibility. These criteria can be assigned higher weights to reflect this importance in the final point scores. A panel of local experts should be formed to assign weighting factors and determine the value of each criterion. 


\section{References}

1. State Park and Ride Lot Program. Working Paper 4: Facility Analysis. Prepared for the Office of Public Transportation, Florida Department of Transportation, by Frederic R Harris, Inc., Tallahassee, Florida, October 1989.

2. Kerchowskas, K. and Sen, A.K. Ride Sharing and Park and Ride: An Assessment of Past Experience and Planning Methods for the Future. Volume III: The Park and Ride Planning Manual. Prepared for the Office of University Research, Research and Special Programs Administration, U.S. Department of Transportation by the School of Urban Sciences, University of Illinois at Chicago Circle. Springfield, Virginia: National Technical Information Service, November 1977.

3. State Park and Ride Lot Program. Working Paper 1: Data Development. Prepared for the Office of Public Transportation, Florida Department of Transportation, by Frederic R Harris, Inc., Tallahassee, Florida, October 1989.

4. FDOT District Three Park and Ride Program. Florida Institute for Marketing Alternative Transportation, Florida State University, Tallahassee, Florida, 1995.

5. Shearin, Guillame. National Ridesharing Demonstration Program: Employer and Community Based Rideshare Promotion in Cincinnati, Ohio. Prepared for the Office of Technical Assistance, Urban Mass Transportation Administration by Crain and Associates, Inc., Springfield, Virginia: National Technical Information Service, December 1985.

6. National Ridesharing Demonstration Program: Employer-Based Rideshare Promotion in Atlanta, Georgia. Prepared for the Office of Management Research and Transit Services, Urban Mass Transportation Administration by Charles River Associates, Inc., Springfield, Virginia: National Technical Information Service, May 1985.

7. Ewing, R. Pedestrian and Transit Friendly Design. Florida DOT, March 1996.

8. Burns, E.N. Priority Rating of Potential Park-and-Ride Sites. ITE Journal, Institute of Transportation Engineers, Washington, D.C., February 1979.

9. Guide for the Design of High Occupancy Vehicle and Public Transfer Facilities. Washington, D.C.: American Association of State Highway and Transportation Officials, 1983.

10. SR 94 Urban Corridor PTO Conceptual Design Study. Final Report. Prepared for the District VI Public Transportation Office, Florida Department of Transportation by Frederic R. Harris, Inc.(formerly PRC Engineering, Inc.), Miami, Florida, 1985. 


\section{CHAPTER 4: DEMAND AND FACILITY SIZE ESTIMATION}

This chapter presents methods for estimating lot demand and lot space requirements for urban corridor, peripheral, urban fringe, and remote park-and-ride facilities. In general, methods are provided for two types of application for each lot type: systems-planning applications, where quick estimates of demand are required, and project planning applications, required in lot design.

The worked examples provided in this chapter will be helpful in executing the formulas and procedures. All of the methods are easily implemented within a spreadsheet provided the necessary input databases are available.

\section{ANALYSIS PHILOSOPHY}

Scale, complexity and project cost should govern the type of approach used for estimating size requirements for park-and-ride facilities. In most cases, sketch planning techniques based on local travel and socio-economic data are preferred to sophisticated and data intensive modeling techniques. In cases where the capital investment is relatively large, such as those associated with HOV lanes and rail systems, the accuracy of sketch planning techniques can be satisfactorily improved upon with more detailed and current data.

Determining the size requirement for a park-and-ride facility consists of eight steps:

1. Computing the number of motorists that will utilize the facility

2. Converting the number of motorists to the number of parked vehicles

3. Adjusting the number of parked vehicles to account for fluctuations in demand created by seasonal factors

4. Computing the maximum accumulation of kiss-and-ride vehicles

5. Computing the number of handicapped spaces required

6. Converting the number of spaces to an area measure

7. Calculating additional space requirements for bus facilities

8. Developing space allowances for landscaping, setbacks, drainage, etc.

The techniques presented in this chapter are based on the assumption that the facility will be optimally located and implemented in the area for which size analyses are being performed. Usage will not reach expected levels if a facility is not visible, not promoted, is located in an unsafe area, or has poor access.

The descriptions in this chapter include the context in which the method can be applied, data requirements and sources, methods of synthesizing data which may not be available or too costly to compile, and appropriate adjustments which may need to be considered based on the conditions of the proposed improvement.

\section{OUTLINE OF CHAPTER}

As there are several different methods for demand and facility size estimation, depending on the type of facility and scale of analysis, the user should select the method that is most appropriate for the given context. The following table provides a roadmap of the methods presented in this chapter so that a user 
may quickly and easily identify the preferred method and appropriate section of this chapter for a certain problem.

Table 4-1

Roadmap of Methods Presented in Chapter

\begin{tabular}{lccc}
\multicolumn{1}{c}{ Facility Type } & Type of Analysis & $\begin{array}{c}\text { Description of } \\
\text { Method }\end{array}$ & Worked Example \\
\hline Remote Facility & Sketch Planning & Page 4-2 & Page 4-3 \\
Peripheral Facility & Project Planning & Page 4-5 & Page 4-8 \\
Urban Fringe Facility & Sketch Planning & Page 4-10 & Page 4-13 \\
Specific Transit Facility & Project Planning & Page 4-14 & Page 4-25 \\
\hline
\end{tabular}

\section{REMOTE FACILITIES}

Size estimation for remote lots is based on observations of parking and right-of-way availability [1]. The demand observation technique is most applicable in areas where population within the lot service area and employment in the destination area are not expected to grow excessively. The further the site is from an urban area, the greater the applicability of this technique.

A concern associated with this technique is that providing a park-and-ride facility in a rural area does not insure its use by those observed to be parking at informal locations. Experience has shown that informal parking continues in spite of the construction of a conveniently located park-and-ride lot [2, 3].

\section{Data Required}

The data required for this method are minimal and easily obtained.

- Observations of actual informal parking

- Population data at the home end

- Employment data at the destination end

\section{Methodology}

The methodology involves counting existing informal parking and then adjusting for growth and expected error.

STEP 1: Identify parking activity surrounding the candidate site. This determines the existing parking requirement and should be performed by an individual or study team familiar with the area, commuting patterns, and employment or activity centers where commuters are going. Definition of the area in which to perform the counts will be highly variable because of roadway configurations, location of commute routes, and population.

STEP 2: Select a design year and compute an appropriate growth factor. The easiest factor to compute is based on projections of population within the service area of the lot, employment in the urban area(s) which the lot serves, or a combination of population and employment projections. 
Population forecast data is the easiest to obtain, since the University of Florida publishes this information annually in its Florida Statistical Abstract [4]. Projections are provided in five-year increments for each county in Florida. Unless other conditions prevail, the population growth for the county in which the lot is to be located can be used for the adjustment of base-year parking.

Future year employment data can be obtained from the FSUTMS urban area data sets, or from the State Department of Labor and Employment Security. If the growth factor is based on employment, one should be careful not to confuse labor force with employment. Labor force is associated with the place of residence, while employment is associated with the workplace. For this method, data for employment is appropriate.

The following formula is typically used to combine population and employment growth:

Growth Factor $=\mathrm{SQRT}\left[\mathrm{F}_{\text {pop }} \times \mathrm{F}_{\mathrm{emp}}\right]$

where:

$\mathrm{F}_{\text {pop }}=$ Population growth factor

$\mathrm{F}_{\mathrm{emp}}=$ Employment growth factor

STEP 3: Compute the design year parking demand. Multiply the existing number of parkers observed in Step 1 by the growth factor computed in Step 2. This estimate of future design year parking demand may need to be adjusted based on the experience that estimates at remote lots tend to be overstated. As mentioned above, construction of a remote lot does not insure its use by those observed to be parking at unauthorized locations nearby. Consideration should be given to adjusting the computed estimate of demand to account for this.

The downward adjustment should be based on local knowledge of public travel behavior and perceptions, potential effectiveness of increased parking enforcement, and amount of citizen requests and complaints associated with facility provision. As a guideline for deriving an appropriate factor, the utilization of remote lots in Florida is usually no more than 30 to 40 parked vehicles.

STEP 4: Convert total parking space requirements to an area measure. A factor of 300 square feet per space should be used. This factor includes areas required for parking, circulation, and access. Keep in mind that right-of-way availability often constrains or dictates the size of remote facilities. In situations where right-of-way is being provided at an existing facility, the estimate must also take into consideration parking requirements generated by that facility during coinciding hours of use.

\section{SAMPLE CALCULATIONS: REMOTE FACILITIES}

This section provides sample tables and calculations for the demand and facility size estimation of remote facilities. The tables demonstrate the application of the method in a step-by-step manner similar to that provided in the description in the previous section.

\section{Data Required}

1. Count of actual informal parking (Step 1)

2. Population data at the home end and employment data at the destination end for both base (current) and forecast (design) years. 


\section{Step 2: Compute an Appropriate Growth Factor}

Let: $\operatorname{Pop}_{\mathrm{c}}=$ population at home end in current year

$\mathrm{Pop}_{\mathrm{d}}=$ population at home end in design year

$\mathrm{Emp}_{\mathrm{c}}=$ employment at destination end in current year

$\mathrm{Emp}_{\mathrm{d}}=$ employment at destination end in design year

$\mathrm{F}_{\text {pop }}=$ population growth factor

$\mathrm{F}_{\mathrm{emp}}=$ employment growth factor

Table 4-2

Current Year: 2001

Step 2: Compute an Appropriate Growth Factor

Design Year: 2006

\begin{tabular}{|c|c|c|c|c|c|c|}
\hline $\begin{array}{l}\text { Pop }_{c} \\
\text { (1) }\end{array}$ & $\begin{array}{l}\text { Pop }_{d} \\
\text { (2) }\end{array}$ & $\begin{array}{c}F_{\text {pop }} \\
(3)=(2) \div(1)\end{array}$ & $\begin{array}{c}E m p_{c} \\
(4)\end{array}$ & $\begin{array}{c}E m p_{d} \\
(5)\end{array}$ & $\begin{array}{c}F_{\mathrm{emp}} \\
(6)=(5) \div(4)\end{array}$ & $\begin{array}{c}\text { Growth Factor } \\
(7)=\operatorname{SQRT}[(3) \times(6)]\end{array}$ \\
\hline 3000 & 3200 & 1.067 & 750 & 850 & 1.133 & 1.100 \\
\hline
\end{tabular}

\section{Step 3: Compute the Design Year Parking Demand}

Let: $\mathrm{AIP}=$ count of actual informal parking (number of vehicles)

Table 4-3

Step 3: Compute the Design Year Parking Demand (number of vehicles)

Current Year: 2001

Design Year: 2006

\begin{tabular}{ccc} 
AlP & $\begin{array}{c}\text { Growth Factor } \\
(\mathbf{1})\end{array}$ & $\begin{array}{c}\text { Design Year Parking Demand } \\
(\mathbf{3})=(\mathbf{1}) \times(\mathbf{2})\end{array}$ \\
\hline 30 & 1.100 & 33
\end{tabular}




\title{
Step 4: Convert Parking Space Requirements to an Area Measure
}

\author{
Table 4-4 \\ Step 4: Convert Parking Space Requirements to an Area Measure \\ (Square Feet) \\ Current Year: 2001 \\ Design Year: 2006

\begin{tabular}{ccc}
$\begin{array}{c}\text { Design Year Parking Demand } \\
\text { (1) }\end{array}$ & $\begin{array}{c}\text { Area per Space } \\
(\mathbf{2})\end{array}$ & $\begin{array}{c}\text { Design Year Area Measure } \\
(\mathbf{3})=(\mathbf{1}) \times(\mathbf{2})\end{array}$ \\
\hline 33 & $300 \mathrm{sq} \mathrm{ft}$ & $9,900 \mathrm{sq} \mathrm{ft}$
\end{tabular}

\section{PERIPHERAL FACILITIES}

Peripheral park-and-ride facilities are designed to supplement parking deficiencies in highly congested or access-restrained activity centers. As such, the size requirements can be determined from estimates of the parking deficiencies, with considerations for transit usage and the distribution of existing parking supply.

Spatial distribution of existing parking supply is also important. Parking facilities that are located too close to each other can result in underutilization, even if the activity center, as a whole, has parking deficiencies.

Another consideration is the availability of shuttle transit service. Such service is highly recommended, since it increases the area in which a new parking facility can be constructed and increases the opportunity for finding a suitable site. If shuttle transit service is not provided, the parking facility will need to be located within comfortable walking distance of high activity areas.

\section{Data Required}

The following data is required for computing the size of peripheral facilities:

- Traffic analysis zone (TAZ) map of the activity center area

- Street map of the activity center area

- Design year employment for the activity center

- Mode share distribution for home-based work trips to the activity center, if available

- Traffic counts for major arterials accessing the activity center

- Parking inventory

The TAZ map and design year employment and population can be obtained from the urban area data sets maintained by the area's Metropolitan Planning Organization (MPO) and/or FDOT District Planning Office. Interpolation may be necessary if the base or planning years of these data are not consistent with those of the sizing analysis.

Traffic counts for State facilities are available from FDOT District Offices. Counts for county and city facilities are available from the county and city governments. In some communities, the MPO or other local agency compiles and publishes traffic counts from all jurisdictions with scheduled traffic count programs. 
An inventory of parking spaces may need to be performed. Such inventories may already exist and can be obtained by contacting the local parking authority, city, county, and/or MPO. The inventory should concentrate on spaces in public and private surface lots and structures, but should also include curb spaces.

\section{Methodology}

Calculate the parking requirements for home-to-work trip parking at the activity center, based on the activity center employment. Total parking deficiency within the activity center is then computed by comparing the parking demand with available parking. Estimates of parking demand that can be captured by the new facility are based on assessments of site location and distribution of existing parking supply. Finally, site size requirements are computed considering costs of construction and anticipated revenue.

STEP 1: Estimate total parking demand for the activity center. Identify the traffic analysis zones (TAZs) contained in the activity center. The "Total Employment" variable contained in FSUTMS ZDATA files is then accumulated for these zones. The resulting value represents work trips for the activity center. Total parking demand for work trips on a person-trip basis is computed by subtracting transit usage from the total activity center employment. The local mode split distributions from the urban area models can be used to factor out transit usage. If local data are not available, the mode split data in Table 4-5 can be used. These data were developed from the Florida Standard Model documentation [5] and findings from other areas $[6,7,8]$. Miami's modal shares may be used for larger metropolitan areas with rail transit and the Volusia shares for smaller metropolitan areas.

Table 4-5

Peripheral Park-and-Ride Facility

Home-Base Work Mode Share Data

\begin{tabular}{lccc}
\multicolumn{1}{c}{ Area Type } & Drive Alone & Carpools & Transit \\
\hline Large Urban Area w/ Rail Transit [6, 8] & 0.75 & 0.15 & 0.10 \\
Large/Moderate Size Urban Area w/o Rail Transit [5] & 0.81 & 0.12 & 0.06 \\
Small Urban Area [7] & 0.87 & 0.11 & 0.02 \\
\hline
\end{tabular}

Parking demand is then computed by dividing the number of work-purpose person trips by the vehicle occupancy. Local occupancy values should be used and can be found in the urban area model documentation and mode split model setups. Table 4-6 contains vehicle occupancy rates that can be used in lieu of local data. 
Table 4-6

Home-Based Work Trip Auto Occupancies

(persons per vehicle)

\begin{tabular}{lc}
\multicolumn{1}{c}{ Source } & Rate \\
\hline 1996 Tampa Bay Regional Survey [9] & 1.12 \\
2000 Southeast Florida Regional Survey [10] & 1.15 \\
1995 National Survey [7] & 1.10 \\
\hline
\end{tabular}

Total parking demand is finally computed by dividing the work trip parking demand by the ratio of work trip and total parking in the activity center.

Total Parking Demand $=\frac{\left[\operatorname{Emp} \times\left(1-\mathrm{T}_{\text {share }}\right)\right]}{\left[\operatorname{Occ} \times \mathrm{R}_{\mathrm{w}}\right]}$

where:

$$
\begin{array}{ll}
\text { Emp } & =\text { Total activity center employment } \\
\mathrm{T}_{\text {share }} & =\text { Proportion of work trips using transit } \\
\text { Occ } & =\text { Average auto occupancy for activity center work trips } \\
\mathrm{R}_{\mathrm{w}} & =\text { Proportion of total parking used for work trip parking }
\end{array}
$$

Table 4-7 presents distributions of activity center parking by trip purpose that can be used to obtain values for $\mathrm{R}_{\mathrm{w}}$. The work trip factor is selected based on the population of the entire urban area in which

\begin{tabular}{|c|c|c|c|c|}
\hline $\begin{array}{l}\text { Urban Area } \\
\text { Population }\end{array}$ & $\begin{array}{c}\text { Work } \\
(\%)\end{array}$ & $\begin{array}{c}\text { Shopping } \\
(\%)\end{array}$ & $\begin{array}{c}\text { Personal } \\
\text { Business (\%) }\end{array}$ & $\begin{array}{c}\text { Other } \\
(\%)\end{array}$ \\
\hline$<25,000$ & 21 & 38 & 23 & 18 \\
\hline $25,000-50,000$ & 21 & 27 & 35 & 17 \\
\hline $50,000-100,000$ & 20 & 24 & 31 & 25 \\
\hline $100,000-250,000$ & 26 & 21 & 34 & 19 \\
\hline $250,000-500,000$ & 30 & 19 & 33 & 18 \\
\hline $500,000-1,000,000$ & 47 & 13 & 25 & 15 \\
\hline$>1,000,000$ & 41 & 10 & 30 & 19 \\
\hline
\end{tabular}
the study is being conducted.

Table 4-7

Distribution of Activity Center Parking By Trip Purpose $\left(\mathbf{R}_{\mathrm{w}}\right)$

(Reference 10)

STEP 2: Determine parking supply deficiency. The following formula is used to determine the parking supply deficiency:

Parking Deficiency $=$ Total Parking Demand - Supply

Supply $\quad=$ Existing parking supply obtained from parking inventory 
Equation 2 defines a parking deficiency if a positive value is produced. However, a negative value does not necessarily indicate that there is sufficient parking throughout the entire activity center; subareas within the activity center may be under-supplied.

STEP 3: Compute the maximum number of parking vehicles the facility can capture. This is based on the orientation of the parking facility to important access routes. Identify the roads that provide access to the area in which the parking facility is to be located. Then, calculate the maximum number of parkers using the facility:

Maximum Parking Capture $=$ Parking Deficiency $\times\left(\mathrm{V}_{\mathrm{adj}} / \mathrm{V}_{\mathrm{all}}\right)$

where:

$$
\begin{aligned}
& \mathrm{V}_{\text {adj }}=\begin{array}{l}
\text { Traffic volume on the adjacent roadways from which parkers are expected to } \\
\text { access the parking facility. }
\end{array} \\
& \mathrm{V}_{\text {all }}=\begin{array}{l}
\text { Total traffic volume on commuting arterials and highways accessing the } \\
\text { activity center. }
\end{array}
\end{aligned}
$$

STEP 4: Determine parking demand. Compare the supply of existing parking in the vicinity of the new facility with the maximum number of potential parkers computed in Step 3. This is to be done because not all of the parking capture computed in Step 3 is going to use the new park-n-ride facility. Some of the parking capture computed in Step 3 will utilize other available parking in the area. Therefore, an adjustment needs to be made to compute the actual parking demand for a new park-n-ride facility. This requires consideration of the final destinations and circulation patterns of activity center parkers, as well as the location and amount of existing parking in relation to these destinations and circulation patterns. This is a subjective assessment; therefore a team approach is recommended.

STEP 5: Determine the facility size requirement. The actual parking demand computed in Step 4 is utilized to determine the facility size requirement. Both surface lots and parking garages are possible options. Parking spaces, circulation, access and possibly transit parking areas should be considered. Compute the size requirements for surface and structural facilities as follows:

$$
\begin{array}{ll}
\text { Surface Lot: Size (acres) } & =\frac{[(300 \times S)+(240 \times B)]}{43,560} \\
\text { Garage: Size (acres) } & =\frac{[\{325 \times(S \div F)\}+(240 \times B)]}{43,560}
\end{array}
$$

where:

$\mathrm{S}=$ Number of parking spaces (actual parking demand from Step 4)

$\mathrm{B}=$ Number of bus bays

$\mathrm{F}=$ Number of floors of parking structure/garage 


\section{SAMPLE CALCULATIONS: PERIPHERAL FACILITIES}

This section provides sample tables and calculations for the demand and facility size estimation of peripheral facilities. The tables demonstrate the application of the method in a step-by-step manner similar to that provided in the description in the previous section.

\section{Data Required}

1. Activity center employment, say from urban model ZDATA file.

2. Home-based work mode share data, say from urban model mode split step.

3. Home-based work trip vehicle occupancy data, say from urban model mode split step.

4. Activity center parking inventory from local data source or field data collection exercise.

\section{Step 1: Compute Total Parking Demand}

Let: $\quad \mathrm{EMP}=$ Total activity center employment

$\mathrm{T}_{\text {share }}=$ Proportion of work trips using transit

Occ $=$ Average vehicle occupancy for activity center work trips

$\mathrm{R}_{\mathrm{w}} \quad=$ Proportion of parking spaces used for work trip parking

\begin{tabular}{|c|c|c|c|c|c|}
\hline \multicolumn{6}{|c|}{$\begin{array}{l}\text { Table 4-8 } \\
\text { Step 1: Compute Total Parking Demand }\end{array}$} \\
\hline $\begin{array}{l}\text { EMP } \\
\text { (1) }\end{array}$ & $\begin{array}{c}T_{\text {share }} \\
(2)\end{array}$ & $\begin{array}{c}1-\mathrm{T}_{\text {share }} \\
(3)=1.00-(2)\end{array}$ & $\begin{array}{l}\text { Occ } \\
(4)\end{array}$ & $\begin{array}{l}R_{w} \\
(5)\end{array}$ & $\begin{array}{l}\text { Total Parking Demand } \\
\begin{array}{c}(6)=[(1) \times(3)] \div[(4) \times \\
(5)]\end{array}\end{array}$ \\
\hline 800 & 0.06 & 0.94 & 1.10 & 0.26 & 2,629 \\
\hline
\end{tabular}

Step 2: Compute Parking Deficiency

Table 4-9

Step 2: Compute Parking Deficiency

\begin{tabular}{ccc}
$\begin{array}{c}\text { Total Parking Demand } \\
(\mathbf{1})\end{array}$ & $\begin{array}{c}\text { Parking Supply } \\
(\mathbf{2})\end{array}$ & $\begin{array}{c}\text { Parking Deficiency (PD) } \\
(\mathbf{3})=(\mathbf{1})-(\mathbf{2})\end{array}$ \\
\hline 2,629 & 1,800 & 829
\end{tabular}

\section{Step 3: Compute Maximum Parking Capture}

Let: $\mathrm{V}_{\mathrm{adj}}=$ Traffic volume on the adjacent roadways from which parkers are expected to access the facility

$\mathrm{V}_{\text {all }}=$ Total traffic volume on commuting arterials and highways accessing the activity center 
Table 4-10

Step 3: Compute Maximum Parking Capture

\begin{tabular}{cccc}
$\begin{array}{c}\text { Parking Deficiency } \\
\text { (PD) }\end{array}$ & $\begin{array}{c}\mathbf{V}_{\text {adj }} \\
(\mathbf{2})\end{array}$ & $\begin{array}{c}\mathbf{V}_{\text {all }} \\
(\mathbf{3})\end{array}$ & $\begin{array}{c}\text { Max Parking Capture } \\
(\mathbf{4})=(\mathbf{1}) \times[(\mathbf{2}) \div(\mathbf{3})]\end{array}$ \\
\hline 829 & & & 663
\end{tabular}

\section{Step 4: Determine Actual Parking Demand}

This is a subjective assessment of the actual parking demand. It may be determined by comparing the supply of existing parking in the vicinity of the new facility with the maximum number of potential parkers computed in Step 3. Suppose the assessment yields an available parking supply in the vicinity of the new facility of 300 spaces. Then, the actual parking demand for the new facility $=663-300=$ 363 spaces.

Step 5: Determine Facility Size Requirement

\begin{tabular}{|c|c|c|c|c|}
\hline \multicolumn{5}{|c|}{$\begin{array}{c}\text { Table 4-11 } \\
\text { Step 5: Compute Facility Size Requirement }\end{array}$} \\
\hline $\begin{array}{l}\text { Type of Facility } \\
\text { (1) }\end{array}$ & $\begin{array}{l}\text { Spaces } \\
\text { (2) }\end{array}$ & $\begin{array}{l}\text { Bus Bays } \\
\text { (3) }\end{array}$ & $\begin{array}{l}\text { Floors } \\
\text { (4) }\end{array}$ & $\begin{array}{cc}\text { Facility Size } \\
\text { Surface: }(5)=[300 \times(2)+240 \times(3)] \div 43,560 \\
\text { Garage: }(5)=[325 \times\{(2) \div(4)\}+240 \times(3)] \div \\
43,560\end{array}$ \\
\hline Surface lot & 363 & 10 & -- & 2.56 acres \\
\hline Garage & 363 & 10 & 4 & 0.73 acres \\
\hline
\end{tabular}

\section{SKETCH PLANNING FOR URBAN FRINGE FACILITIES}

The methodology presented here is for use in assessing urban fringe lot development. This approach may also be used for urban corridor facilities; however, the level of accuracy will decrease as the number of commuting roads increases.

The methodology for estimating facility sizes for urban fringe lots is an adaptation of the ITE model [11, 14]. This model assumes that parking demand is a function of the amount of traffic on roadways adjacent to the park-and-ride facility. It is a simple technique, requiring only peak period volumes on roads that provide access to the park-and-ride lot.

This approach is best applied in areas where there are a limited number of commuting roadways. The ITE model assumes that commuters will not divert from their normal travel routes and that users come only from commute routes adjacent to the park-and-ride facility. These assumptions are realistic in areas with a very few number of commute routes. 


\section{Data Required}

Data required for the model includes the following:

- AM peak hour traffic counts in 15-minute increments for roads from which the lot is expected to attract parkers. If 15-minute counts are not available, total peak-hour counts as well as 24-hour traffic counts with appropriate $\mathrm{K}$ (peak hour percentage) and D (peak hour directional distribution) factors can be used.

- Facility type of the commute roadways adjacent to the lot

- Area type of the adjacent roadways.

\section{Methodology}

The ITE technique for estimating fringe lot demand is:

Demand $=\left(\mathrm{a} \times \mathrm{V}_{\mathrm{p}}\right)+\left(\mathrm{b} \times \mathrm{V}_{\mathrm{s}}\right)$

where:

$\mathrm{V}_{\mathrm{p}}=$ Total design period traffic on adjacent primary facilities

$\mathrm{V}_{\mathrm{s}}=$ Design period traffic on adjacent secondary facility

$a, b=$ Diversion factors for traffic on the primary and secondary facilities

This technique involves factoring peak period traffic. The design period is the period of time during the peak period when a facility experiences the highest traffic flows. In this application, the design period is equivalent to the peak hour only for facilities carrying over 50,000 ADT. The design period concept supports the theory that park-and-ride use is related to congestion levels, and is supported by observations showing arrivals at park-and-ride facilities during a well-defined time period. This postulates that motorists traveling during times of greatest congestion will have a greater propensity to utilize park-and-ride.

The following steps are used to compute size requirements for fringe facilities:

STEP 1: Collect traffic data for affected roadways. Identify the primary and secondary roadways that are expected to produce parkers. The primary roadway is considered to be the main commuting roadway in the vicinity of the park-and-ride lot. Secondary roadways are commuting routes of lesser importance, producing fewer numbers of parkers.

Ideal data consists of 15-minute peak-period traffic counts by direction for the primary and secondary roadways. Hourly counts or 24-hour counts can be used if 15-minute counts are not available. Assumptions concerning peak hour percentages ( $\mathrm{K}$ factor) and directional distribution of traffic (D factor) will be necessary if peak hour or directional counts are not available.

STEP 2: Determine the design period. The design period should represent that time in which there is a pronounced peaking of traffic on the facility. The accuracy of the demand estimate is sensitive to the design-period traffic. It is not necessary that the design period equal the conventional peak period or peak hour. A plot of 15-minute traffic or observations of actual traffic flows in the field are useful methods for determining this time period. Table 4-12 presents design period values that were developed in this study for roadways carrying the indicated 24-hour traffic volumes. These can be used in lieu of actual 15-minute counts or traffic observations. 
Table 4-12

Suggested Design Periods

\begin{tabular}{cc} 
ADT & Design Period \\
\hline Above 50,000 & 60 minutes \\
$35,000-49,999$ & 45 minutes \\
Below 35,000 & 30 minutes \\
\hline
\end{tabular}

STEP 3: Calculate the design period traffic. If 15-minute counts are available, accumulate these counts as required to derive the traffic flow during the design period. With hourly count data, an assumption of an even distribution of traffic during the hour can be made. If 24-hour counts are used, $\mathrm{K}$ and D factors will need to be assumed. Table 4-13 presents typical values for these factors and are provided for use in situations where local data is not available. The FDOT District PD\&E/Programming office should be consulted for the local $\mathrm{K}$ and $\mathrm{D}$ factors applicable to pertinent roadways.

\begin{tabular}{lcc}
\multicolumn{3}{c}{ Table 4-13 } \\
Generalized K and D Factors \\
\multicolumn{1}{c}{ Roadway Class } & K & D \\
\hline Collectors and Local Streets & 0.09 & 0.6 \\
Major and Minor Arterials & 0.09 & 0.6 \\
Suburban Multi-Lane Highways & 0.11 & 0.6 \\
Suburban Freeways & 0.09 & 0.6 \\
Urban Freeways & 0.09 & 0.6 \\
Rural Two-Lane Highways & 0.11 & 0.6 \\
Rural Multi-Lane Highways & 0.11 & 0.6 \\
Rural Freeways & 0.11 & 0.6 \\
\hline (Reference 14) & &
\end{tabular}

STEP 4: Estimate the Lot Size. Compute the parking demand for the facility as follows:

Demand $=\mathrm{a} \times \mathrm{V}_{\mathrm{p}}+\mathrm{b} \times \mathrm{V}_{\mathrm{s}}$ where:

$\mathrm{V}_{\mathrm{p}}=$ Total design period traffic on adjacent primary facilities

$\mathrm{Vs}=$ Design period traffic on adjacent secondary facilities

$\mathrm{a}=0.03$ representing a capture of three percent on primary facilities

$\mathrm{b}=0.01$ representing a capture of one percent on secondary facilities

Lot size requirements can then be determined by multiplying the demand by an appropriate adjustment factor and dividing the result by 300 square feet per parking space for surface facilities and 325 square feet times the number of floors for structures. It is recommended that the adjustment should provide for at least a 25 percent increase over the demand using the ITE model. This would plan for an 80 percent occupancy rate. The factor may also include adjustments for seasonal variations in traffic counts. These factors can be obtained from the local District Statistics office. The following formulas may be used:

Surface lot: $\quad$ Size $(\mathrm{sq} \mathrm{ft})=$ Demand $\times 1.25 \times 300$ 
Garage: $\quad$ Size $(\mathrm{sq} \mathrm{ft})=$ Demand $\times 1.25 \times 325 \div \mathrm{F}$

Table 4-14 presents the results of executing the above procedure using actual data. The input consisted of the latest 24-hour counts on the primary and secondary facilities, default values for the design period, and $\mathrm{K}$ and $\mathrm{D}$ factors derived from Table 4-13. The procedure provided reasonable estimates of demand, compared to actual utilization counts provided by the Department.

Table 4-14

ITE Model Test Results Using Florida Data

\begin{tabular}{lcccccc}
\multicolumn{1}{c}{ Location } & ADT & K & D & $\begin{array}{c}\text { Design } \\
\text { Period }\end{array}$ & $\begin{array}{r}\text { Demand } \\
\text { Estimate }\end{array}$ & $\begin{array}{c}\text { Observed } \\
\text { Usage }\end{array}$ \\
\hline Ft Myers & $\mathrm{V}_{\mathrm{p}}=16,600$ & 0.11 & 0.6 & 30 & 21 & 24 \\
SR 82 \& Ortiz & $\mathrm{V}_{\mathrm{s}}=14,100$ & 0.11 & 0.6 & 30 & & \\
& $\mathrm{~V}_{\mathrm{p}}=54,100$ & 0.09 & 0.6 & 60 & & \\
Jacksonville & $\mathrm{V}_{\mathrm{s}}=25,100$ & 0.11 & 0.6 & 30 & 96 & \\
SR 13\& I-295 & $\mathrm{V}_{\mathrm{p}}=22,700$ & 0.11 & 0.6 & 30 & & 25 \\
Milton & $\mathrm{V}_{\mathrm{s}}=7,200$ & 0.11 & 0.6 & 30 & & \\
US90 \& SR 281 & $\mathrm{V}_{\mathrm{p}}=35,000$ & 0.09 & 0.6 & 30 & & \\
Broward County & $\mathrm{V}_{\mathrm{s}}=18,500$ & 0.11 & 0.6 & 30 & & 28 \\
I-75 \& Pines Blvd. & & & & & & \\
Tampa & $\mathrm{V}_{\mathrm{p}}=19,700$ & 0.11 & 0.6 & 30 & 20 & 18 \\
SR 597 \& Lakeview & & & & & & \\
\hline
\end{tabular}

\section{SAMPLE CALCULATIONS: URBAN FRINGE FACILITIES}

This section provides sample tables and calculations for the demand and facility size estimation of urban fringe facilities. The tables demonstrate the application of the method in a step-by-step manner similar to that provided in the description in the previous section.

\section{Data Required}

1. Traffic volume counts for the adjacent primary and secondary facilities, preferably 15 -minute counts so that the design period can be identified (Step 1).

\section{Step 2: Determine the Design Period}

In this step, the time-of-day distribution of the hourly or 15-minute traffic counts is examined to identify a design period. Table 4-12 provides default values if detailed traffic count data is not available. 


\section{Step 3: Compute the Design Period Traffic}

Let: $\quad \mathrm{ADT}_{\mathrm{p}}=$ Two-way average daily traffic for the primary facility

$\mathrm{ADT}_{\mathrm{s}}=$ Two-way average daily traffic for the secondary facility

$\mathrm{K}=$ Peak hour percentage (refer to Table 4-13 for default values)

$\mathrm{D}=$ Peak hour directional distribution of traffic (refer to Table 4-13 for default)

$\mathrm{DP}=$ Design period, the pronounced peak traffic period, identified from the 15 minute traffic counts or suggested value from Table 4-12 (in minutes)

\begin{tabular}{|c|c|c|c|c|c|}
\hline \multicolumn{6}{|c|}{$\begin{array}{c}\text { Table 4-15 } \\
\text { Step 3: Compute the Design Period Traffic }\end{array}$} \\
\hline $\begin{array}{c}\text { Type of } \\
\text { Facility } \\
\text { (1) }\end{array}$ & $\begin{array}{l}\text { ADT } \\
(2)\end{array}$ & $\begin{array}{l}\text { K-factor } \\
\text { (3) }\end{array}$ & $\begin{array}{l}\text { D-factor } \\
\text { (4) }\end{array}$ & $\begin{array}{l}\text { DP } \\
(5)\end{array}$ & $\begin{array}{l}\text { Design Period Traffic, V } \\
(6)=(2) \times(3) \times(4) \times(5) \div 60\end{array}$ \\
\hline Primary & 50000 & 0.10 & 0.60 & 60 & 3000 \\
\hline Secondary & 35000 & 0.09 & 0.65 & 30 & 1024 \\
\hline
\end{tabular}

Step 4: Compute the Parking Demand and Estimate the Facility Size

Table 4-16

Step 3: Compute the Parking Demand

\begin{tabular}{|c|c|c|c|c|}
\hline $\begin{array}{l}V_{p} \\
(1) \\
\end{array}$ & $\begin{array}{l}V_{s} \\
(2) \\
\end{array}$ & $\begin{array}{c}a \\
(3) \\
\end{array}$ & $\begin{array}{c}b \\
(4)\end{array}$ & $\begin{array}{c}\text { Parking Demand } \\
(5)=(1) \times(3)+(2) \times(4)\end{array}$ \\
\hline 3000 & 1024 & 0.03 & 0.01 & 100 \\
\hline
\end{tabular}

Table 4-17

Step 5: Compute Facility Size Requirement

\begin{tabular}{ccccc}
$\begin{array}{c}\text { Type of Facility } \\
\text { (1) }\end{array}$ & $\begin{array}{c}\text { Spaces } \\
(\mathbf{2})\end{array}$ & $\begin{array}{c}\text { Adj } \\
\text { Factor } \\
\mathbf{( 3 )}\end{array}$ & $\begin{array}{c}\text { Floors } \\
\mathbf{( 4 )}\end{array}$ & $\begin{array}{c}\text { Facility Size (square feet) } \\
\text { Surface: (5) }=(\mathbf{2}) \times(\mathbf{3}) \times \mathbf{3 0 0} \\
\text { Garage: (5) }=(\mathbf{2}) \times(\mathbf{3}) \times \mathbf{3 2 5} \div \mathbf{( 4 )}\end{array}$ \\
\hline $\begin{array}{c}\text { Surface lot } \\
\text { Garage }\end{array}$ & 100 & 1.25 & -- & 37,500 \\
\hline
\end{tabular}

\section{DETAILED METHODOLOGY FOR TRANSIT FACILITIES}

The methodology presented in this section is an adaptation of a similar procedure used to estimate the park-and-ride lot size requirements for the I-95 reconstruction project in Southeast Florida [15]. In that work, considerations for HOV facilities, the Tri-County Commuter Rail system, and carpooling were required. The procedure is applicable in any urban area where new or additional change-of-mode fringe parking facilities are under consideration [16].

Of all the methodologies presented in this chapter, this is the most complex and rigorous. Urban area transportation model data can be used as inputs to these methods to expedite the process. The following broad steps comprise the procedures: 
1. Delineate origin and destination market influence areas and identify the transportation analysis zones contained in each influence area.

2. Estimate total daily person trip interchanges between the origin and destination market influence area.

3. Estimate the proportion of trips that will use line-haul or carpool modes.

4. Estimate the proportion of daily line-haul riders that will use the change-of-mode parking facility.

The procedure described below is used in situations where transit influences need to be addressed by the demand estimation procedure. This suggests that the approach is best applied in planning facilities which will contain hundreds of spaces, such as major urban corridor lots, HOV parking facilities, and transit transfer terminals. Any facility study to be reviewed by a federal agency should use this approach.

\section{Data Required}

Some of the data used in the methodology may not be available or may be too time-consuming to acquire. Consequently, some of the data listed serve as alternatives to the preferred data elements. The reader should consult the individual step descriptions to determine exactly which data will be required for the application and circumstances.

- Street map encompassing the service and final destination areas.

- Urban area traffic analysis zone map.

- Dwelling unit and employment data by traffic analysis zone. These data are included in the FSUTMS data sets for the urban area and are needed if a trip table is not available.

- Urban area trip generation rates. Required if trip table data are not available.

- Origin-destination person-trip tables generated by the urban area FSUTMS-based model for the design year of the facility.

- Urban area mode split model coefficients for the modes under consideration.

\section{Methodology}

Seven steps define the lot size requirements. Alternative data development procedures are also included to assist the user with methods for formulating data that may not be available.

The most complex set of calculations are Steps 3 through 6. These are included in order to estimate the impacts on park-and-ride facility size produced by transit services, parking costs, and congestion. The procedure is a simplified approach, to be used in lieu of the FSUTMS modeling procedures.

Figure 4-1 shows the process for deriving parking requirements at a facility located in an urban transit corridor. The methodology follows the nested logit mode split model formulation. The first step is to determine the primary modal splits for person trips between the origin and destination market influence areas. The primary modes differ by size of urban area. Typically, larger urban areas will have line-haul transit services available, while smaller areas will not. Consequently, modeling in larger urban areas requires consideration of a larger number of primary modes.

The second step consists of splitting the primary modal shares into submodes. As an example, the primary mode split model determines the proportion of trips by the drive-alone auto mode. The second- 
level mode split model then determines the drive-alone trips utilizing a park-and-ride lot and those that will not.

The logit formulation of the mode split model follows:

$$
\begin{aligned}
\mathrm{DU}_{\mathrm{m}} & =\mathrm{a} \times \mathrm{IVTT}_{\mathrm{m}}+\mathrm{b} \times \mathrm{OVTT}_{\mathrm{m}}+\mathrm{c} \times \mathrm{PK}_{\mathrm{m}}+\mathrm{d} \times \mathrm{OC}_{\mathrm{m}}+\mathrm{Bias}_{\mathrm{m}} \\
\mathrm{P}_{\mathrm{m}} & =\frac{\operatorname{EXP}\left(-\mathrm{DU}_{\mathrm{m}}\right)}{\sum_{\text {modes }} \operatorname{EXP}\left(-\mathrm{DU}_{\mathrm{m}}\right)}
\end{aligned}
$$

where:

$$
\begin{aligned}
& \mathrm{DU}_{\mathrm{m}} \quad=\text { Disutility of mode } \mathrm{m} \\
& \text { IVTT }_{\mathrm{m}}=\text { In-vehicle travel time for mode } \mathrm{m} \\
& \text { OVTT }_{\mathrm{m}}=\text { Out-of-vehicle travel time for mode } \mathrm{m} \\
& \mathrm{PK}_{\mathrm{m}} \quad=\text { Parking cost and toll charges for mode } \mathrm{m} \\
& \mathrm{OC}_{\mathrm{m}}=\text { Other out-of-pocket costs such as fares or auto operating cost } \\
& \mathrm{a}, \mathrm{b}, \mathrm{c}, \mathrm{d}=\text { Model coefficients } \\
& \text { Bias }_{\mathrm{m}} \quad=\text { Modal bias constant for mode } \mathrm{m} \\
& \mathrm{P}_{\mathrm{m}} \quad=\text { Probability of using mode } \mathrm{m} \\
& \mathrm{EXP} \quad=\text { Exponential function } \\
& \text { modes }=\text { All modes considered at the level of mode split analysis being } \\
& \text { performed. Up to seven modes will be useful in larger urban areas, } \\
& \text { while as few as four may be considered in smaller areas. }
\end{aligned}
$$

The following steps include alternate data development procedures to give the user methods for formulating data that may not be available. 
Figure 4.1: Nested Logit Model Structure

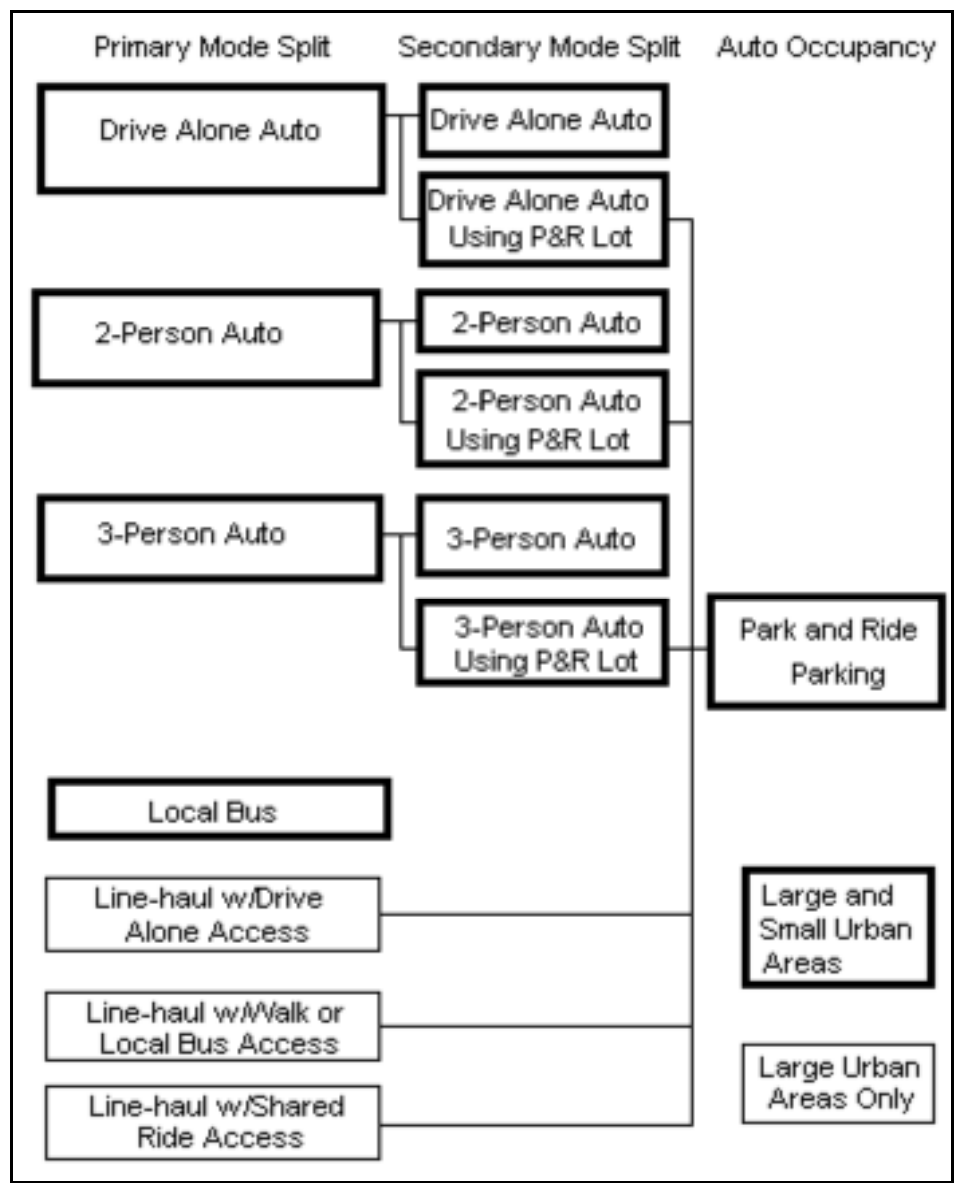

STEP 1A: Delineate the origin market influence area. Most formulations are based on home-to-lot travel distance, which ignores the influence of traffic congestion on service area and market size. The following will assist in the delineation of the origin market influence area for the site under consideration:

A. Use sound judgment. Both the results of this study and the research findings indicate that parkers travel a limited distance (or time) to access a park-and-ride facility. The tendency will be to define market areas that are too large.

B. Land development patterns, configuration of the access street network, and the level of mobility on that network are the most significant influences on the service area.

C. Motorists will not travel significant distances out of their normal commuting paths to take advantage of a park-and-ride facility.

D. Upward of 90 percent of park-and-ride lot users in an urban environment live within five miles of the facility.

E. Park-and-ride facilities in close proximity to each other will tend to redistribute parkers and 
produce only a marginal increase in facility usage.

The procedure for delineating the market influence area begins with computing the maximum distance from the lot to the outside limits of the service area.

Maximum Access Distance (miles) $=\frac{\text { Time }}{60} \times$ Speed $_{\text {avg }} \times \frac{1}{\text { CFAC }}$

where:

$$
\begin{aligned}
& \text { Time }=\text { Maximum driving time to lot (minutes) } \\
& \text { Speed }=\text { Average home-to-lot operating speed (miles per hour) } \\
& \text { CFAC }=\text { Circuitry factor }
\end{aligned}
$$

Approximately 90 percent of the parkers at urban fringe and corridor lots come from within five miles or about 12 minutes [4]. This is consistent with findings from other areas [11].

Assumptions of average travel speed for accessing urban fringe and corridor park-and-ride lots should consider the development type and roadway level of service. A value of $25 \mathrm{mph}$ is typically used for trips traveling primarily on arterials. A value of $35 \mathrm{mph}$ or more may be appropriate if the lot access trip is made predominantly on limited-access highways; a lesser value would be assumed if trips are primarily on local streets.

The circuitry factor is used to convert the length of trip over the road to equivalent airline distance. Typical factors range from 1.1 to 1.3; however, the choice of this factor should be based on review of the access road network and the population distribution in the potential service area.

The perimeter of the market area should be plotted on a base map using the maximum access distance computed above. In general, a circular market area may be assumed unless additional information that warrants using a different shape is available. For example, one may also use an elliptical market area (where the maximum access distance is equal to the major axis of the ellipse). The shape and size of the area should be influenced by practical knowledge of travel patterns, street network, geography, and existing or proposed park-and-ride facilities that affect demand for the proposed improvement.

Caution should be exercised if two or more park-and-ride lots are in close proximity and share a common market influence area. In such a case, adjustments to the area boundary are required. One consideration is that the first lot encountered will be used. Furthermore, backtracking will not occur if another facility can be accessed in the direction of travel.

STEP 1B: Delineate the destination market influence area. The destination market influence area will comprise areas of significant employment concentrations. Employment and zone area data contained in the FSUTMS ZDATA files, in conjunction with the associated traffic analysis zone map, can be used to identify destination zones. Special generator data should also be reviewed to identify other zones that have large employment concentrations.

A quick way of identifying TAZs to be included in the destination market influence area is to sort the FSUTMS ZDATA file containing the employment data on the TOTAL EMPLOYMENT and ZONE 
fields. Records for the zones considered to be likely destinations can be extracted, re-sorted on the ZONE field, and printed to generate a simple list of the zones to be considered.

Without these data, local knowledge of employment location, travel patterns from the origin market influence area, and the commuting road network must be relied on to identify the destination areas. For reference purposes, the destination market influence areas should be delineated on the TAZ map, as well as a street map.

STEP 2: Determine total number of trips from origin influence area to the destination influence area. Two methods are presented for developing interchange volumes. The easiest method requires staff to be knowledgeable in the application of the FSUTMS modeling software. Using FSUTMS modeling procedures and reporting routines, trip tables showing trip interchanges by trip purpose between every zone pair can be extracted.

It will usually suffice to perform the above procedures only on the home-base work trip; however, there may be cases where other trip purposes, such as home-base shopping trips, will significantly contribute to lot demand. In these situations, trip interchange listings should also be extracted from the FSUTMS model tables associated with these trip purposes.

Trip tables should be extracted for the desired design year. In cases where the model forecast year is not the same as the desired design year for facility size estimation, suitable interpolation techniques may be applied. In addition, base year trip tables may be used with an expansion factor applied to represent the growth in the origin and destination areas. An expansion factor can be developed using the following formula:

$$
\begin{aligned}
& f_{o d}=\left[1+\operatorname{SQRT}\left(f_{o} \times f_{d}\right)\right] \\
& \text { where: } \\
& \qquad \begin{aligned}
f_{o d}= & \text { Composite growth factor for trip interchanges between the origin and destination } \\
& \text { market areas }
\end{aligned} \\
& f_{o}=\text { Growth factor for the origin market influence area } \\
& f_{d}=\text { Growth factor for the destination market influence area }
\end{aligned}
$$

The origin and destination growth factors in the above equation are based on population and employment growth between the base and design years.

In lieu of available trip tables, an alternative method can be used to develop the number of trip interchanges between the origin and destination influence areas. 


$$
\mathrm{TRIP}_{\mathrm{od}}=\mathrm{DU}_{0} \times \frac{\mathrm{HBW}}{2} \times \frac{\mathrm{Emp}_{\mathrm{d}}}{\mathrm{Emp}_{\text {tot }}} \times \frac{\mathrm{L}_{\mathrm{avg}}}{\mathrm{D}_{\mathrm{p}}}
$$

where:

$\mathrm{TRIP}_{\mathrm{od}}=$ Number of trips from the origin area to the destination area

$\mathrm{DU}_{0}=$ Dwelling units in the origin market influence area with one or more autos

$\mathrm{HBW}=$ Home-base work trip rate

$\mathrm{Emp}_{\mathrm{d}}=$ Destination area employment

$\mathrm{Emp}_{\text {tot }}=$ Total urban area employment

$\mathrm{L}_{\text {avg }}=$ Average home-base work trip length

$\mathrm{D}_{\mathrm{p}}=$ Average distance between the origin and destination influence areas

The formula defines the number of trips from the origin influence area to the destination market influence area as a function of the:

- total number of home-base work trips generated in the origin influence area

- destination area's share of the total urban area employment

- difference between the average trip length from the origin area to the destination area and the average home-base trip length for the entire urban area.

The number of one and two-plus dwelling units in the origin market influence area is contained in the FSUTMS ZDATA files of the urban area models. Local home-base work trip rates can be used to develop an average HBW trip factor for one and two-plus auto households. Average trip lengths for the urban area can be found in the urban area FSUTMS model distribution output. Table 4-18 presents factors that may be applied if trip rate and length data are not available.

Table 4-18

Florida Urban Area Home-Base Work Trip Rates

\begin{tabular}{lcc} 
Urban Area & $\begin{array}{c}\text { Person Trips Per } \\
\text { Household }\end{array}$ & $\begin{array}{c}\text { Average Trip Length } \\
\text { (miles) }\end{array}$ \\
\hline Gainesville & $1.30^{1}$ & \\
Jacksonville & $1.72^{1}$ & $9.6^{3}$ \\
Lee County & $1.14^{1}$ & \\
Palm Beach & $1.46^{1}$ & \\
Tampa Bay & $1.21^{1}$ & $9.0^{2}$ \\
Tallahassee & $1.80^{1}$ & $6.8^{3}$ \\
Volusia & $1.14^{1}$ & \\
Pasco & $1.08^{2}$ & $13.0^{2}$ \\
Pinellas & $1.51^{2}$ & $6.1^{2}$ \\
Dade & $1.55^{2}$ & $8.0^{3}$ \\
Broward & $1.59^{1}$ & $6.0^{3}$ \\
Palm Beach & $1.57^{1}$ & $7.1^{3}$ \\
\hline & ${ }^{1}$ Reference 12 & \\
& ${ }^{2}$ Reference 9 &
\end{tabular}

STEP 3: Estimate the input variables to the mode split model. The input data for the mode under 
consideration must be developed. These data relate to in-vehicle travel time, out-of-vehicle travel time, parking cost, and other out of pocket costs. If line-haul transit is being considered, data for up to ten modes will need to be developed, consistent with the multi-path transit assignment method described in the FSUTMS documentation [5].

1. Drive alone auto

2. 2-person carpools

3. 3+ person carpools

4. Local bus

5. Line-haul transit with walk or local bus access

6. Line-haul transit with drive alone auto access

7. Line-haul transit with shared ride auto access

8. Carpool formed at the park-and-ride facility with drive alone access

9. Carpool formed at the park-and-ride facility with 2-person shared ride auto access

10. Carpool formed at the park-and-ride facility with $3+$ person shared ride auto access

If line-haul transit is not to be considered, data for up to seven modes will need to be generated, consistent with the single-path transit assignment method also included in the FSUTMS documentation [5].

1. Drive alone auto

2. 2-person carpools

3. 3+ person carpools

4. Local bus

5. Carpool formed at the park-and-ride facility with drive alone access

6. Carpool formed at the park-and-ride facility with 2-person shared ride auto access

7. Carpool formed at the park-and-ride facility with $3+$ person shared ride auto access

Table 4-19 describes the data requirements for the mode split model and includes data definitions, sources of the data, and typical default values.

In developing variable values for non-park-and-ride auto modes (1, 2, and 3), assume that the travel path is from home directly to the work destination. Data for the local bus mode should also be from home directly to the work destination. Data may not need to be generated for this mode if its share of trips is expected to be insignificant.

Line-haul transit data should include the park-and-ride facility if line-haul service is provided. The model assumes that competing line-haul routes do not exist. If this is not the case, data should be generated for the travel path with the shortest time. A secondary mode split will then need to be executed for the various line-haul modes to split them between the various lines.

If HOV facilities are considered in the analysis, the in-vehicle travel time (IVTT) values for the carpool and line-haul modes should include these facilities in the travel path from the origin to destination ends of the morning commute trip. Study of direct access ramps to the HOV facility is performed through use of the out-of-vehicle travel time (OVTT) value. Time to travel back and forth between the mainline commute roadway and the parking facility is added to the OVTT value. HOV lane usage increases by 50 to 100 percent as a result of direct access ramps [17]. 
Table 4-19

Mode Split Input Variables

\begin{tabular}{|c|c|c|c|}
\hline Variable & Definition & Source & Default \\
\hline Origin Terminal Time & $\begin{array}{l}\text { Time required to leave trip origin } \\
\text { zone in minutes }\end{array}$ & $\begin{array}{l}\text { Zonal terminal time in urban model } \\
\text { data }\end{array}$ & 1 minute \\
\hline Walking Time & $\begin{array}{l}\text { Average walking time from origin to } \\
\text { transit stop in minutes }\end{array}$ & $\begin{array}{l}\text { Estimate based on local land } \\
\text { development and bus stop spacing }\end{array}$ & 5 minutes \\
\hline Waiting Time & $\begin{array}{l}\text { Average wait time for bus arrival in } \\
\text { minutes }\end{array}$ & $\begin{array}{l}1 / 2 \text { of published headway, } 10 \\
\text { minute maximum }\end{array}$ & 10 minutes \\
\hline Transfer Time & $\begin{array}{l}\text { Average time required to transfer } \\
\text { between routes in minutes }\end{array}$ & $1 / 2$ of published headway & 5 minutes \\
\hline Lot Access Time & $\begin{array}{l}\text { Time between main line route and } \\
\text { park-and-ride facility including } \\
\text { parking time in minutes }\end{array}$ & $\begin{array}{l}\text { Based on the distance between } \\
\text { mainline route and park-and-ride lot } \\
\text { and congestion }\end{array}$ & Not Applicable \\
\hline Destination Egress Time & $\begin{array}{l}\text { Walking time from last transit } \\
\text { vehicle to final destination in } \\
\text { minutes }\end{array}$ & $\begin{array}{l}\text { Estimate based on transit stop } \\
\text { spacing }\end{array}$ & 5 minutes \\
\hline Destination Terminal Time & $\begin{array}{l}\text { Time of travel between last vehicle } \\
\text { used and final destination in } \\
\text { minutes }\end{array}$ & $\begin{array}{l}\text { Zonal terminal time in urban model } \\
\text { data }\end{array}$ & 5 minutes \\
\hline Drive Time & $\begin{array}{l}\text { Time spent in auto from origin to } \\
\text { the final destination for auto modes, } \\
\text { or from origin to the park- and-ride } \\
\text { lots excluding lot access time in } \\
\text { minutes }\end{array}$ & $\begin{array}{l}\text { Urban area model skims or speed } \\
\text { and delay survey data }\end{array}$ & $\begin{array}{l}\text { Estimate based on } \\
\text { trip distance and } \\
\text { average travel speed } \\
\text { assumptions ranging } \\
\text { from } 25 \text { to } 45 \mathrm{mph} \\
\text { based on nature of } \\
\text { travel path }\end{array}$ \\
\hline Line-haul Run Time & $\begin{array}{l}\text { In-vehicle time in line-haul transit } \\
\text { vehicle in minutes }\end{array}$ & Published or proposed schedule & Not Applicable \\
\hline Local Bus Run Time & $\begin{array}{l}\text { In-vehicle time on local bus in } \\
\text { minutes }\end{array}$ & $\begin{array}{l}\text { Published or proposed bus } \\
\text { schedule }\end{array}$ & Not Applicable \\
\hline Tolls & $\begin{array}{l}\text { Road and bridge tolls divided by } \\
\text { number of occupants in vehicle in } \\
\text { dollars }\end{array}$ & $\begin{array}{l}\text { Published toll schedules divided by } \\
\text { number of vehicle occupants }\end{array}$ & Not Applicable \\
\hline Auto Operating Cost & $\begin{array}{l}\text { Perceived costs associated with } \\
\text { operating an auto in dollars }\end{array}$ & $\begin{array}{l}\text { Per mile cost of fuel, oil, and } \\
\text { maintenance times trip length }\end{array}$ & $\begin{array}{c}20 \text { cents/mile } \\
(\text { Year } 2000)\end{array}$ \\
\hline Parking Costs & $\begin{array}{l}\text { Parking charges at park-and-ride } \\
\text { facility and at the destination } \\
\text { divided by number of occupants in } \\
\text { the vehicle in dollars }\end{array}$ & $\begin{array}{l}\text { Existing or proposed daily parking } \\
\text { charge divided by number of } \\
\text { vehicle occupants }\end{array}$ & Not Applicable \\
\hline Bus/Line-haul Fare & $\begin{array}{l}\text { One-way transit boarding charge for } \\
\text { local bus and line-haul modes in } \\
\text { dollars }\end{array}$ & Published or proposed fares & Not Applicable \\
\hline Transfer Fare & $\begin{array}{l}\text { Fare to transfer between transit } \\
\text { routes or services in dollars }\end{array}$ & Published transfer charge & Not Applicable \\
\hline
\end{tabular}

STEP 4: Compute disutilities for modes under consideration. The following formula is used to compute disutilities of the various modes being considered: 


$$
\mathrm{DU}_{\mathrm{m}}=\left(0.015 \times \mathrm{IVTT}_{\mathrm{m}}\right)+\left(0.14 \times \mathrm{OVTT}_{\mathrm{m}}\right)+\left(0.021 \times \mathrm{PK}_{\mathrm{m}}\right)+\left(0.005 \times \mathrm{OC}_{\mathrm{m}}\right)+\text { Bias }
$$

where:

$\mathrm{DU}_{\mathrm{m}} \quad=$ Disutility of mode $\mathrm{m}$

$\operatorname{IVTT}_{\mathrm{m}}=$ In-vehicle travel time for mode $\mathrm{m}$

OVTT $_{\mathrm{m}}=$ Out-of-vehicle travel time for mode $\mathrm{m}$

$\mathrm{PK}_{\mathrm{m}} \quad=$ Parking cost and toll charges for mode $\mathrm{m}$

$\mathrm{OC}_{\mathrm{m}} \quad=$ Other out-of-pocket costs such as fares or auto operating cost

Bias $_{\mathrm{m}}=$ Constant for mode $\mathrm{m}$

The bias coefficients to be used in the above equation are found in Tables 4-20 and 4-21. The values of model coefficients are derived from the Tampa Bay Regional Planning Model [18] for the large urban area and the Volusia County Travel Model for the small urban area [19].

Table 4-20

Bias Coefficients for Primary-Level Mode Split Model

\begin{tabular}{ll} 
Mode & Bias \\
\hline Studies in large Urban Areas & \\
1. Drive Alone Auto & 0.00 \\
2. Two-Occupant Auto & 1.58 \\
3. Three-Occupant Auto & 1.75 \\
4. Local Bus w/ Walk Access & 2.74 \\
5. Line-haul w/ Walk or Local Bus Access & 2.45 \\
6. Line-haul w/ Drive Alone Access & 2.56 \\
7. Line-haul w/ Share-Ride Access & 2.49
\end{tabular}

Studies in Small Urban Areas

1. Drive Alone Auto 0.00

2. Two-Occupant Auto 1.78

3. Three-Occupant Auto 2.34

4. Transit 3.31 
Table 4-21

Bias Coefficients for secondary-Level Mode Split Model

\begin{tabular}{lc}
\multicolumn{1}{c}{ Mode } & Bias \\
\hline Studies in Large Urban Areas & \\
1A. Drive Alone Auto Accessing Park-and-Ride Facility & 3.40 \\
2A. 2-Occupant Auto Accessing Park-and-Ride Facility & 4.25 \\
3A. 3+ Occupant Auto Accessing Park-and-Ride Facility & 4.75 \\
& \\
Studies in Small Urban Areas & 3.34 \\
1A. Carpools from Drive Alone Auto & 5.52 \\
2A. Carpools from Two-Occupant Auto & 6.68 \\
3A. Carpools from Three-Occupant Auto &
\end{tabular}

STEP 5: Compute primary-level modal shares. The disutilities computed in Step 4 are input to the following formula to calculate the primary-level modal shares of person trips between the origin and destination market influence areas:

$$
\mathrm{P}_{\mathrm{m}}=\frac{\operatorname{EXP}\left(-\mathrm{DU}_{\mathrm{m}}\right)}{\sum_{\mathrm{i}=1}^{\text {modes }} \operatorname{EXP}\left(-\mathrm{DU}_{\mathrm{i}}\right)}
$$

where:

$$
\begin{aligned}
\mathrm{P}_{\mathrm{m}}= & \text { Probability of using mode } \mathrm{m} \\
\mathrm{DU}_{\mathrm{m}}= & \text { Disutility of mode } \mathrm{m} \\
\mathrm{EXP}= & \text { Exponential function } \\
\text { modes }= & \text { All modes considered as primary modes. Up to seven primary-level modes } \\
& \text { will be used in larger urban areas; as few as four primary-level modes in } \\
& \text { smaller areas. }
\end{aligned}
$$

The disutilities used in the above formula will differ based on the existence of line-haul modes. In large urban areas in Florida, line-haul modes will typically be included in the analysis. In this case, the disutilities for modes 1, 2, 3, 4, 5, 6, and 7 presented in Table 4-20 will be used in this step. In situations where line-haul modes may not be considered, such as in small urban areas, the disutilities for modes 1 , 2,3 , and 4 will be input to the above formula.

STEP 6: Compute secondary-level modal shares. In this step, the modal shares for the primary auto modes calculated in Step 5 are split to determine the number of persons who will use the park-and-ride facility. Input to this step includes the $P_{m}$ values (calculated for modes 1, 2, and 3 in Step 5) and the $\mathrm{DU}_{\mathrm{m}}$ values (calculated for modes 1A, 2A, and 3A in Step 4). These values are input to the following formula: 


$$
\mathrm{P}_{\mathrm{mA}}=\frac{\mathrm{P}_{\mathrm{m}} \times \operatorname{EXP}\left(-\mathrm{DU}_{\mathrm{mA}}\right)}{\left[\operatorname{EXP}\left(-\mathrm{DU}_{\mathrm{m}}\right)+\operatorname{EXP}\left(-\mathrm{DU}_{\mathrm{mA}}\right)\right]}
$$

where:

$$
\begin{aligned}
\mathrm{P}_{\mathrm{mA}}= & \begin{array}{l}
\text { Probability of using park-and-ride facility for mode } \mathrm{m} \text {, where } \mathrm{m} \text { is either } \\
\text { drive alone auto, 2-person auto, or 3+ person auto modes. }
\end{array} \\
\mathrm{P}_{\mathrm{m}}= & \begin{array}{l}
\text { Probability of using mode } \mathrm{m} \text { computed from the Step } 5 \text { primary level } \\
\text { analysis. Mode } \mathrm{m} \text { is either drive alone auto, 2-person auto, or } 3+\text { person } \\
\text { auto modes. }
\end{array} \\
\mathrm{DU}_{\mathrm{mA}}= & \begin{array}{l}
\text { Disutility of using park-and-ride facility, where mode } \mathrm{m} \text { is either drive alone } \\
\text { auto, 2-person auto, or 3+ person auto modes. Computed in Step } 4 .
\end{array} \\
\mathrm{DU}_{\mathrm{m}}= & \begin{array}{l}
\text { Disutility of using auto mode } \mathrm{m}, \text { where mode } \mathrm{m} \text { is either drive alone auto, } \\
\text { 2-person auto, or } 3+\text { person auto modes. Computed in Step } 4 .
\end{array}
\end{aligned}
$$

STEP 7: Determine parking space requirements. Input to this step includes the:

- number of trips between the origin and destination market influence areas (TRIPS ${ }_{\text {od }}$ ) from Step 2 .

- Mode shares for the auto-accessed line-haul modes $\left(\mathrm{P}_{6}\right.$ and $\left.\mathrm{P}_{7}\right)$ from Step 5.

- Mode shares for the three auto modes accessing the park-and-ride facility $\left(\mathrm{P}_{1 \mathrm{~A}}, \mathrm{P}_{2 \mathrm{~A}}\right.$, and $\left.\mathrm{P}_{3 \mathrm{~A}}\right)$ from Step 6.

These values are added to the following formula to compute the number of spaces required for all-day parking:

$$
\begin{aligned}
& \text { Spaces }_{0}=\text { TRIPS }_{\text {od }} \times\left(\mathrm{P}_{1 \mathrm{~A}}+\frac{\mathrm{P}_{2 \mathrm{~A}}}{2}+\frac{\mathrm{P}_{3 \mathrm{~A}}}{3.5}+\mathrm{P}_{6}+\frac{\mathrm{P}_{7}}{2.5}\right) \\
& \text { where: } \\
& \text { Spaces }_{0}=\text { Unadjusted estimate of long-term parking space requirements } \\
& \text { TRIPS }_{\mathrm{od}}=\text { Number of person trips between the origin and destination market } \\
& \text { influence areas calculated in Step } 2 \\
& \mathrm{P}_{1 \mathrm{~A}}=\text { Probability of driving alone to access the park-and-ride facility to form a } \\
& \text { carpool } \\
& \mathrm{P}_{2 \mathrm{~A}}=\text { Probability of accessing the park-and-ride facility in a 2-person carpool } \\
& \text { to form a carpool } \\
& \mathrm{P}_{3 \mathrm{~A}}=\text { Probability of accessing the park-and-ride facility in a } 3+\text { person carpool } \\
& \text { to form a carpool } \\
& \mathrm{P}_{6}=\text { Probability of driving alone to access line-haul transit service at the } \\
& \text { park-and-ride facility } \\
& \mathrm{P}_{7} \quad=\text { Probability of driving in a carpool to access line-haul transit service at } \\
& \text { The park-and-ride facility }
\end{aligned}
$$

The values of 2, 3.5, and 2.5 used as denominators in the above equation represent default auto 
occupancy factors for 2-person, 3+ person, and 2+ person carpools, respectively. Local data can be substituted for these values.

Two additional adjustments need to be made to the above value to account for kiss-and-ride access and for planned utilization in the design year. Approximately 10 to 15 percent of park-and-ride facility patrons access the facility via kiss-and-ride [1]. Use of the 10 percent factor is recommended for two reasons. First, all kiss-and-ride vehicles will not be accessing the facility at the same time. Second, overflow parking can use long-term parking spaces if the space requirement value is under estimated.

In addition, the Spaces $_{0}$ value represents the total projected number of automobiles accessing the park-and-ride facility. This value should be upwardly adjusted to produce an estimate that results in less than 100 percent utilization in the design year. Design policies of the jurisdiction involved, as well as other considerations such as land availability, will dictate the proper adjustment. A 25 percent upward adjustment will produce a space requirement estimate representing a planned utilization of 80 percent in the design year.

The estimate of long-term parking requirements can be further adjusted to account for fuel shortage contingencies. As a point of reference, planners in the Tampa area use an adjustment factor of up to 100 percent. This 100 percent factor accounts for planned under-utilization, energy contingencies, and growth in usage over the base year conditions.

The following formula can be used to compute the total parking space requirements at the facility being analyzed:

$$
\begin{aligned}
\text { Spaces } & =\text { Long-term spaces }+ \text { Kiss-and-ride spaces } \\
& =\text { Spaces }_{0} \times 0.90 \times \mathrm{FAC}+\text { Spaces }_{0} \times 0.10
\end{aligned}
$$

where:

Spaces $_{0}=$ Unadjusted estimate of long-term parking space requirements

FAC $=$ Adjustment factor to provide for less than 100 percent utilization; a default value of $1.20-1.25$ may be used

The final computation converts the number of parking spaces required as computed above to the site size requirement. A conversion factor of 300 square feet per space is recommended for surface lots and 325 square feet per space for parking structures. The following formulas may be used:

$$
\begin{array}{ll}
\text { Surface Lot: Size (acres) } & =\frac{300 \times \mathrm{S}}{43,560} \\
\text { Garage: Size (acres) } & =\frac{325 \times(\mathrm{S} \div \mathrm{F})}{43,560}
\end{array}
$$


where:

$\mathrm{S}=$ Number of parking spaces

$\mathrm{F}=$ Number of floors of parking structure/garage

These factors account for parking space, circulation, and access area requirements.

\section{SAMPLE CALCULATIONS}

This section provides sample tables and calculations for the demand and facility size estimation of urban fringe facilities. The tables demonstrate the application of the method in a step-by-step manner similar to that provided in the description in the previous section. Sample tables used herein are for illustrative purposes only, and do not contain real world data.

\section{Step 2: Alternative Method for Developing Total Daily Trip Interchanges for Corridor Lots}

\section{Data Required}

1. Dwelling units in the origin market influence area, from FSUTMS data sets.

2. Employment in the destination market influence area, from FSUTMS data sets.

3. Average home-based work trip length from local urban model if available.

Let: $\quad$ TRIPS $_{\mathrm{od}}=$ number of trips from origin market area to destination market area

$\mathrm{DU}_{\mathrm{o}} \quad=$ dwelling units with one or more autos in the origin market influence area

$\mathrm{EMP}_{\mathrm{d}}=$ destination area employment

HBW $=$ home-based work trip rate from urban model or Table 4-18

$\mathrm{EMP}_{\text {tot }}=$ total urban area employment by summing employment over all TAZ's in the urban area model

$\mathrm{L}_{\mathrm{avg}}=$ average home-based work trip length from urban model trip distribution output or alternative survey data source

$\mathrm{D}_{\mathrm{p}} \quad=$ average distance between the origin and destination influence areas (measured from map or network)

Table 4-22

Step 2: Alternative Method for Developing Total Daily Trip Interchanges for Corridor Lots

\begin{tabular}{ccccccc}
$\begin{array}{c}\mathrm{DU}_{\mathrm{o}} \\
(\mathbf{1})\end{array}$ & $\begin{array}{c}\mathrm{HBW} \\
\mathbf{( 2 )}\end{array}$ & $\begin{array}{c}\mathrm{EMP}_{\mathrm{d}} \\
\mathbf{( 3 )}\end{array}$ & $\begin{array}{c}\mathrm{EMP}_{\text {tot }} \\
\mathbf{( 4 )}\end{array}$ & $\begin{array}{c}\mathrm{L}_{\text {avg }} \\
\mathbf{( 5 )}\end{array}$ & $\begin{array}{c}\mathrm{D}_{\mathrm{p}} \\
\mathbf{( 6 )}\end{array}$ & $\begin{array}{c}\text { TRIPS }_{\text {od }} \\
(\mathbf{7})=(\mathbf{1}) \times[(\mathbf{2}) \div 2] \times[(3) \div(\mathbf{4})] \times[(\mathbf{5}) \div(\mathbf{6})]\end{array}$ \\
\hline 200000 & 1.60 & 80000 & 300000 & 20 & 10 & 85333
\end{tabular}




\section{Step 3: Estimate the Input Variables to the Mode Split Model}

Table 4-23

Input Data for the Mode Split Calculations

\begin{tabular}{|c|c|c|c|c|c|}
\hline Mode & Variable & $\begin{array}{c}\text { In-Vehicle } \\
\text { Travel } \\
\text { Time (min) }\end{array}$ & $\begin{array}{c}\text { Out-of } \\
\text { Vehicle } \\
\text { Travel } \\
\text { Time (min) }\end{array}$ & $\begin{array}{l}\text { Out of } \\
\text { Pocket } \\
\text { Costs } \\
\text { (dollars) }\end{array}$ & $\begin{array}{c}\text { Other } \\
\text { Costs } \\
\text { (dollars) }\end{array}$ \\
\hline \multirow{7}{*}{$\begin{array}{l}\text { 1. Drive Alone } \\
\text { Auto }\end{array}$} & Origin terminal time & & 1 & & \\
\hline & Drive time & 20 & & & \\
\hline & Destination terminal time & & 5 & & \\
\hline & Tolls & & & 1 & \\
\hline & Parking cost & & & 5 & \\
\hline & Auto operating cost & & & & 2 \\
\hline & Total & 20 & 6 & 6 & 2 \\
\hline \multirow{11}{*}{$\begin{array}{l}\text { 1A. Drive Alone } \\
\text { Auto Accessing } \\
\text { Park-n-Ride } \\
\text { Facility }\end{array}$} & Origin terminal time & & 1 & & \\
\hline & Travel time to lot & 8 & & & \\
\hline & Lot access time & & 5 & & \\
\hline & Lot park cost per occupant & & & 0 & \\
\hline & Wait time & & 10 & & \\
\hline & Lot to destination driving time & 30 & & & \\
\hline & Destination egress time & & 5 & & \\
\hline & Tolls & & & 0 & \\
\hline & Parking cost & & & 0 & \\
\hline & Auto operating cost & & & & 0.50 \\
\hline & Total & 38 & 21 & 0 & 0.50 \\
\hline \multirow{7}{*}{$\begin{array}{l}\text { 2. Two-Occupant } \\
\text { Auto }\end{array}$} & Origin terminal time & & 5 & & \\
\hline & Drive time & 25 & & & \\
\hline & Destination terminal time & & 5 & & \\
\hline & Toll charge/occupant & & & 0.50 & \\
\hline & Parking cost/occupant & & & 2.50 & \\
\hline & Auto operating cost/occupant & & & & 1.25 \\
\hline & Total & 25 & 10 & 3.00 & 1.25 \\
\hline \multirow{11}{*}{$\begin{array}{l}\text { 2A. Two- } \\
\text { Occupant } \\
\text { Carpool } \\
\text { Accessing Park- } \\
\text { n-Ride Facility }\end{array}$} & Origin terminal time & & 5 & & \\
\hline & Travel time to lot & 8 & & & \\
\hline & Lot park cost per occupant & & & 0 & \\
\hline & Lot access time & & 5 & & \\
\hline & Wait time & & 10 & & \\
\hline & Lot to destination driving time & 30 & & & \\
\hline & Destination egress time & & 5 & & \\
\hline & Toll charge per occupant & & & 0 & \\
\hline & Destination park cost per occupant & & & 0 & \\
\hline & Auto operating cost per occupant & & & & 0.50 \\
\hline & Total & 38 & 25 & 0 & 0.50 \\
\hline \multirow{7}{*}{$\begin{array}{l}\text { 3. Three- } \\
\text { Occupant Auto }\end{array}$} & Origin terminal time & & 7 & & \\
\hline & Drive time & 25 & & & \\
\hline & Destination terminal time & & 7 & & \\
\hline & Toll charge per occupant & & & 0 & \\
\hline & Parking cost per occupant & & & 1.00 & \\
\hline & Auto operating cost per occupant & & & & 0.75 \\
\hline & Total & 25 & 14 & 1.00 & 0.75 \\
\hline
\end{tabular}




\begin{tabular}{|c|c|c|c|c|c|}
\hline \multirow{10}{*}{$\begin{array}{l}\text { 3A. 3+ Occupant } \\
\text { Carpool } \\
\text { Accessing Park- } \\
\text { n-Ride Facility }\end{array}$} & Origin terminal time & & 7 & & \\
\hline & Travel time to lot & 8 & & & \\
\hline & Lot park cost per occupant & & & 0 & \\
\hline & Lot access time & & 5 & & \\
\hline & Wait time & & 10 & & \\
\hline & Lot to destination driving time & 30 & & & \\
\hline & Destination egress time & & 5 & & \\
\hline & Destination park cost per occupant & & & 0 & \\
\hline & Auto operating cost per occupant & & & & 0.25 \\
\hline & Total & 38 & 27 & $\mathbf{0}$ & 0.25 \\
\hline \multirow{8}{*}{$\begin{array}{l}\text { 4. Local Bus with } \\
\text { Walk Access }\end{array}$} & Walk time & & 5 & & \\
\hline & Wait time & & 10 & & \\
\hline & Bus run time & 30 & & & \\
\hline & Transfer time & & 5 & & \\
\hline & Destination egress time & & 5 & & \\
\hline & Bus fare & & & & 1.00 \\
\hline & Transfer fare & & & & 0.50 \\
\hline & Total & 30 & 25 & $\mathbf{0}$ & 1.50 \\
\hline \multirow{9}{*}{$\begin{array}{l}\text { 5. Line Haul with } \\
\text { Walk or Local } \\
\text { Bus Access } \\
\text { (large urban area } \\
\text { model only) }\end{array}$} & Walk time & & 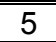 & & \\
\hline & Wait time & & 10 & & \\
\hline & Bus run time & 10 & & & \\
\hline & Transfer time & & 5 & & \\
\hline & Destination egress time & & 5 & & \\
\hline & Local bus fare & & & & 0.50 \\
\hline & Line haul fare & & & & 2.00 \\
\hline & Line haul run time & 25 & & & \\
\hline & Total & 35 & 25 & $\mathbf{0}$ & 2.50 \\
\hline \multirow{11}{*}{$\begin{array}{l}\text { 6. Line Haul with } \\
\text { Drive Alone Auto } \\
\text { Access (large } \\
\text { urban area model } \\
\text { only) }\end{array}$} & Origin terminal time & & 1 & & \\
\hline & Drive time & 8 & & & \\
\hline & Tolls & & & 0 & \\
\hline & Park cost & & & 0 & \\
\hline & Auto operating cost & & & & 0.50 \\
\hline & Lot access time & & 5 & & \\
\hline & Wait time & & 10 & & \\
\hline & Line haul travel time & 25 & & & \\
\hline & Line haul fare & & & & 2.00 \\
\hline & Destination egress time & & 5 & & \\
\hline & Total & 33 & 21 & 0 & 2.50 \\
\hline \multirow{10}{*}{$\begin{array}{l}\text { 7. Line Haul with } \\
\text { Share Ride Auto } \\
\text { Access (large } \\
\text { urban area model } \\
\text { only) }\end{array}$} & Origin terminal time & & 1 & & \\
\hline & Drive time & 8 & & & \\
\hline & Park cost per occupant & & & 0 & \\
\hline & Auto operating cost per occupant & & & & 0.50 \\
\hline & Lot access time & & 5 & & \\
\hline & Wait time & & 10 & & \\
\hline & Line haul travel time & 25 & & & \\
\hline & Line haul fare & & & & 2.00 \\
\hline & Destination egress time & & 5 & & \\
\hline & Total & 33 & 21 & 0 & 2.50 \\
\hline
\end{tabular}




\section{Step 4: Compute Disutilities for Modes Under Consideration}

\section{Data Required}

1. Input data from Step 3 for mode split calculations.

2. Modal bias constants from Tables 4-20 and 4-21 and modal disutility equation from Step 4

Let: $\quad$ IVTT $=$ in-vehicle travel time

OVTT $=$ out-of-vehicle travel time

$\mathrm{PK}=$ out-of-pocket costs

$\mathrm{OC}=$ other costs

$\mathrm{DU}_{\mathrm{i}}=$ disutility of mode $\mathrm{i}$

$=\left(0.015 \times \operatorname{IVTT}_{\mathrm{m}}\right)+\left(0.14 \times \mathrm{OVTT}_{\mathrm{m}}\right)+\left(0.021 \times \mathrm{PK}_{\mathrm{m}}\right)+\left(0.005 \times \mathrm{OC}_{\mathrm{m}}\right)+$ Bias

Table 4-24

Step 4: Compute Disutilities for Modes Under Consideration

(Large Urban Area Corridor Lots)

Mode IVTT OVTT PK OC Bias

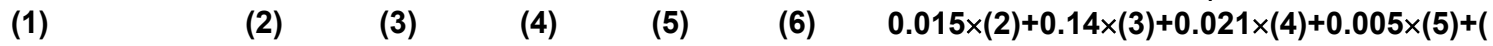

\begin{tabular}{|c|c|c|c|c|c|c|}
\hline 1. Drive alone auto & 20 & 6 & 6 & 2 & 0 & 6) \\
\hline 2. 2-occupant auto & 25 & 10 & 3 & 1.25 & 1.58 & 3.424 \\
\hline 3. 3+-occupant auto & 25 & 14 & 1 & 0.75 & 1.75 & 4.110 \\
\hline $\begin{array}{c}\text { 4. Local bus w/walk } \\
\text { access }\end{array}$ & 30 & 25 & 0 & 1.50 & 2.74 & 6.698 \\
\hline $\begin{array}{c}\text { 5. Line haul w/walk or } \\
\text { local bus access }\end{array}$ & 35 & 25 & 0 & 2.50 & 2.45 & 6.488 \\
\hline $\begin{array}{c}\text { 6. Line haul w/drive } \\
\text { alone access }\end{array}$ & 33 & 21 & 0 & 2.50 & 2.56 & 6.008 \\
\hline $\begin{array}{c}\text { 7. Line haul w/shared- } \\
\text { ride access }\end{array}$ & 33 & 21 & 0 & 2.50 & 2.49 & 5.938 \\
\hline $\begin{array}{c}\text { 1A. Drive alone auto } \\
\text { accessing park-n- } \\
\text { ride facility }\end{array}$ & 38 & 21 & 0 & 0.50 & 3.40 & 6.913 \\
\hline $\begin{array}{c}\text { 2A. 2-occupant auto } \\
\text { accessing park-n- } \\
\text { ride facility }\end{array}$ & 38 & 25 & 0 & 0.50 & 4.25 & 8.323 \\
\hline $\begin{array}{c}\text { 3A. 3+-occupant auto } \\
\text { accessing park-n- } \\
\text { ride facility }\end{array}$ & 38 & 27 & 0 & 0.25 & 4.75 & 9.101 \\
\hline
\end{tabular}


(Small Urban Area Corridor Lots)

Mode $\quad$ IVTT OVTT $\quad$ PK $\quad$ OC Bias $\quad$ DU $_{i}$

$\begin{array}{lllllll}(1) & (2) & (3) & (4) & (5) & \text { (6) } & 0.015 \times(2)+0.14 \times(3)+0.0\end{array}$

\begin{tabular}{|c|c|c|c|c|c|c|}
\hline 1. Drive alone auto & 20 & 6 & 6 & 2 & 0 & 1.276 \\
\hline 2. 2-occupant auto & 25 & 10 & 3 & 1.25 & 1.78 & 3.624 \\
\hline 3. 3+-occupant auto & 25 & 14 & 1 & 0.75 & 2.34 & 4.699 \\
\hline 4. Transit & 30 & 25 & 0 & 1.50 & 3.31 & 7.268 \\
\hline $\begin{array}{l}\text { 1A. Carpools from } \\
\text { drive alone auto }\end{array}$ & 35 & 25 & 0 & 2.50 & 3.34 & 7.378 \\
\hline $\begin{array}{l}\text { 2A. Carpools from } \\
\text { two-occupant auto }\end{array}$ & 33 & 21 & 0 & 2.50 & 5.52 & 8.968 \\
\hline $\begin{array}{l}\text { 3A. Carpools from 3+- } \\
\text { occupant auto }\end{array}$ & 33 & 21 & 0 & 2.50 & 6.68 & 10.128 \\
\hline
\end{tabular}

\section{Step 5: Compute Primary Level Modal Shares}

\section{Data Required}

1. Disutility values calculated in Step 4 .

Let: $\quad \mathrm{DU}_{\mathrm{i}}=$ disutility of mode $\mathrm{i}$

$\mathrm{P}_{\mathrm{i}}=$ probability of choosing mode $\mathrm{i}$

$\mathrm{NE}_{\mathrm{i}}=$ exponential of $-\mathrm{DU}_{\mathrm{i}}$

$\mathrm{SNE}=$ sum of all $\mathrm{NE}_{\mathrm{i}}{ }^{\prime} \mathrm{S}$

Table 4-25

Step 5: Compute Primary Level Modal Shares

(Large Urban Area Corridor Lots)

Mode

(1)

1. Drive alone auto

2. 2-occupant auto

3. 3+-occupant auto

4. Local bus w/walk access

5. Line haul w/walk or local bus access

6. Line haul w/drive alone access

7. Line haul $w /$ shared-ride access
$\mathrm{DU}_{\mathrm{i}}$

(2)

1.276

3.424

4.110

6.698

6.488

6.008

5.938

Sum $(\mathrm{SNE})=$

$\mathrm{NE}_{\mathrm{i}}$ (3) $=\exp [-(2)]$

SNE

(4)=Sum (3) $\quad(5)=(3) \div(4)$

0.279

0.0326

0.0164

0.00123

\begin{tabular}{l|l}
0.00152 & 0.336
\end{tabular}

0.00246

0.00264

0.336

\begin{tabular}{|c|c}
\hline .336 & 0.831 \\
\hline
\end{tabular}

\begin{tabular}{l|l}
0.336 & 0.0969
\end{tabular}

\begin{tabular}{l|l}
0.336 & 0.0488
\end{tabular}

\begin{tabular}{l|l}
0.336 & 0.0488 \\
\hline 0.336 & 0.00367
\end{tabular}

\begin{tabular}{l|l}
0.336 & 0.00453
\end{tabular} 
(Small Urban Area Corridor Lots)

Mode $\quad \mathrm{DU}_{\mathrm{i}} \quad \mathrm{NE}_{\mathrm{i}} \quad \mathrm{SNE} \quad \mathrm{P}_{\mathrm{i}}$

$\begin{array}{lllll}(1) & (2) & (3)=\exp [-(2)] & (4)=\text { Sum } & (5)=(3) \div(4)\end{array}$

\begin{tabular}{|l|c|c|c|c|}
\hline 1. Drive alone auto & 1.276 & 0.279 & 0.316 & 0.884 \\
\hline 2. 2-occupant auto & 3.624 & 0.0267 & 0.316 & 0.0845 \\
\hline 3. 3+-occupant auto & 4.699 & 0.00910 & 0.316 & 0.0288 \\
\hline 4. Transit & 7.268 & 0.000698 & 0.316 & 0.00221 \\
\hline \multicolumn{4}{|c}{ Sum (SNE) $=$} & 0.316
\end{tabular}

\section{Step 6: Compute Secondary Level Modal Shares}

\section{Data Required}

1. Modal disutility values calculated in Step 4 and the primary modal shares calculated in Step 5.

Let: $\quad \mathrm{DU}_{\mathrm{iA}}=$ disutility of secondary level mode iA

$\mathrm{P}_{\mathrm{iA}}=$ probability of choosing mode $\mathrm{iA}$

$\mathrm{NE}_{\mathrm{iA}}=$ exponential of $-\mathrm{DU}_{\mathrm{iA}}$

$\mathrm{iA}=$ notations for secondary level modes, $\mathrm{i}=1$ to 3

Table 4-26

Step 6: Compute Secondary Level Modal Shares

(Large Urban Area Corridor Lots)

$\begin{array}{llllll}\text { Mode } & \mathrm{DU}_{\mathrm{iA}} & \mathrm{NE}_{\mathrm{iA}} & \mathrm{NE}_{\mathrm{i}} & \mathrm{P}_{\mathrm{i}} & \mathrm{P}_{\mathrm{iA}}\end{array}$

(1)

(2)

(3) $=\exp [-(2)]$

(4)

(5)

Table 4-25 Table 4-25

$(6)=[(5) \times(3)] \div[(3)+(4)$

Table 4-24

\begin{tabular}{|l|c|c|c|c|c|}
\hline $\begin{array}{l}\text { 1. Drive alone auto accessing } \\
\text { park-n-ride facility }\end{array}$ & 6.913 & 0.000995 & 0.279 & 0.831 & 0.00295 \\
\hline \begin{tabular}{l} 
2. $\begin{array}{l}\text { 2-occupant auto accessing } \\
\text { park-n-ride facility }\end{array}$ \\
\hline $\begin{array}{l}\text { 3+-occupant auto accessing } \\
\text { park-n-ride facility }\end{array}$
\end{tabular} & 8.323 & 0.000243 & 0.0326 & 0.0969 & 0.000718 \\
\hline
\end{tabular}

(Small Urban Area Corridor Lots)

$\begin{array}{llllll}\text { Mode } & \mathrm{DU}_{\mathrm{iA}} & \mathrm{NE}_{\mathrm{iA}} & \mathrm{NE}_{\mathrm{i}} & \mathrm{P}_{\mathrm{i}} & \mathrm{P}_{\mathrm{iA}}\end{array}$

(1)

(2) $\quad(3)=\exp [-$

(4)

(5) Table 4-25 Table 4-25

\begin{tabular}{|l|c|c|c|c|c|}
\hline $\begin{array}{l}\text { 1. Carpools from drive alone } \\
\text { auto }\end{array}$ & 7.378 & 0.000625 & 0.279 & 0.884 & 0.00198 \\
\hline $\begin{array}{l}\text { 2. Carpools from 2-occupant } \\
\text { auto }\end{array}$ & 8.968 & 0.000127 & 0.0267 & 0.0845 & 0.000402 \\
\hline $\begin{array}{l}\text { 3. Carpools from 3+ occupant } \\
\text { auto }\end{array}$ & 10.128 & 0.0000399 & 0.00910 & 0.0288 & 0.000126 \\
\hline
\end{tabular}

Step 7: Compute Parking Space Requirements

Data Required 
1. Number of person trips between the origin and destination market influence areas (from Step 2).

2. Results of Steps 5 and 6 (i.e., primary and secondary level modal shares).

Let: $\quad$ Spaces $_{0}=$ unadjusted estimate of long-term parking space requirements

Spaces $=$ adjusted number of long-term parking space requirements

TRIPS $_{\text {od }}=$ number of person trips between the origin and destination market areas

TRIPS $_{\mathrm{i}}=$ number of vehicle trips by mode $\mathrm{i}$

$\mathrm{Occ}_{2}=$ Occupancy for two-occupant auto. Default value of 2 occupants/vehicle may be used

$\mathrm{Occ}_{3}=$ Occupancy for $3+$ occupant auto. Default value of 3.5 occupants/vehicle may be used

FAC $=$ Adjustment factor to provide for less than 100 percent utilization; a default value of 1.25 may be used

Table 4-27

Step 7: Compute Parking Space Requirements (Unadjusted)

(Large Urban Area Corridor Lots)

Mode

(1)

TRIPS $_{\text {od }}$

(2)

$P_{i}$ (3)

Occ TRIPS $_{\mathrm{i}}=$

Tables

Table 4-22 4-25 \& 4-26

(4) Spaces $_{0}$ $(5)=(2) \times(3) \div(4)$

Spaces $(\mathrm{FAC}=1.25)$

$(6)=[(5) \times 0.9 \times \mathrm{FAC}]+[(5) \times 0.1]$

\begin{tabular}{|l|c|c|c|c|c|}
\hline $\begin{array}{c}\text { 1. Drive alone auto } \\
\text { accessing park- } \\
\text { n-ride facility }\end{array}$ & 85333 & 0.00295 & 1 & 252 & 309 \\
\hline $\begin{array}{c}\text { 2. 2-occupant auto } \\
\text { accessing park- } \\
\text { n-ride facility }\end{array}$ & 85333 & 0.000718 & 2 & 31 & 38 \\
\hline $\begin{array}{l}\text { 3. 3+-occupant } \\
\text { auto accessing } \\
\text { park-n-ride } \\
\text { facility }\end{array}$ & 85333 & 0.000330 & 3.5 & 8 & 10 \\
\hline $\begin{array}{l}\text { 4. Line haul } \\
\text { w/drive alone } \\
\text { access }\end{array}$ & 85333 & 0.00732 & 1 & 625 & 766 \\
\hline $\begin{array}{l}5 . \\
\text { Line haul } \\
\text { w/share-ride } \\
\text { access }\end{array}$ & 85333 & 0.00785 & 2.5 & 268 & 328 \\
\hline
\end{tabular}




\section{(Small Urban Area Corridor Lots)}

Mode $\quad$ TRIPS $_{\text {od }}$ P $_{\mathrm{iA}}(3)$ Occ TRIPS $_{\mathrm{i}}=$

(1) (2) Tables (4) $\quad$ Spaces $_{0}$

Table 4-22 4-25 \& 4-26

Spaces $(\mathrm{FAC}=1.25)$

$(6)=[(5) \times 0.9 \times \mathrm{FAC}]+[(5) \times 0.1]$

\begin{tabular}{|c|c|c|c|c|c|}
\hline $\begin{array}{c}\text { 1. Carpools from } \\
\text { drive alone auto }\end{array}$ & 85333 & 0.00198 & 1 & 169 & 207 \\
\hline $\begin{array}{c}\text { 2. Carpools from 2- } \\
\text { occupant auto }\end{array}$ & 85333 & 0.000402 & 2 & 17 & 21 \\
\hline $\begin{array}{c}\text { 3. Carpools from 3+ } \\
\text {-occupant auto }\end{array}$ & 85333 & 0.000126 & 3.5 & 3 & 4 \\
\hline
\end{tabular}




\section{References}

1. State Park and Ride Lot Program. Working Paper 4: Facility Analysis. Prepared for the Office of Public Transportation, Florida Department of Transportation, by Frederic R Harris, Inc., Tallahassee, Florida, October 1989.

2. Grice, B. District III, Florida Department of Transportation. Chipley, Florida. Interview. August 3, 1989.

3. Fernandez, T. Q. District V, Florida Department of Transportation. Orlando, Florida. State Park and Ride Program Progress Meeting \#2. October 19, 1989

4. Florida Statistical Abstract. Bureau of Economic Research, College of Business Administration. Gainesville, Florida: University of Florida. Annual Publication.

5. Urban Transportation Planning Model Update, Phase III. "Task II Final Report: Modal Split Model Refinement and Calibration Standards." Prepared for the Florida Department of Transportation by Schimpeler-Corradino Associates. Tallahassee, Florida. May 1984.

6. Christainson, D.L. Alternative Mass Transportation Technologies Technical Data. Prepared for the Transportation Planning Division, Texas Department of Highways and Public Transportation by the Texas Transportation Institute, Texas A \& M University, Springfield, Virginia: National Technical Information Service. December 1985.

7. Klinger, D. \& Kuzmyak, J.R. Personal Travel in the United States, Volume II, 1983-84 Nationwide Personal Transportation Study. Prepared for the Federal Highway Administration by COMSIS Corporation. Springfield, Virginia: National Technical Information Service. September 1986.

8. Wattleworth, J.A., Courage, K.G., Long, G. \& Wallace, C.E. I-95/NW $7^{\text {th }}$ Avenue Bus/Carpool Priority System Evaluation. "Report II-1: Evaluation of the I-95 Express Bus and High Occupancy Vehicle Priority System." Prepared for the Florida Department of Transportation by the Department of Civil Engineering, University of Florida. Springfield, Virginia: National Technical Information Service. January 1978.

9. Pasco, Pinellas, Hillsborough Travel Characteristics Evaluation. Final Report. Prepared for the Bureau of Multimedia Systems Planning, Florida Department of Transportation. Tallahassee, Florida. April 1986.

10. Special Report 125. "Parking Principles." Washington, D.C.: Highway Research Board. 1971. 
11. Bowler, C.E., Noel, E.C., Peterson, R. \& Christiansen, D. Park and Ride Facilities Guidelines for Planning Design and Operation. Prepared for the Office of Traffic Operations Traffic Engineering Division, Federal Highway Administration by Daniel Consultants, Inc. and Texas Transportation Institute. Springfield, Virginia: National Technical Information Service. January 1986.

12. Southeast Regional Planning Model Validation and Alternate Transportation Strategies (SERPM/ATS). "Technical Memorandum 1: Trip Generation Model." Prepared for the Bureau of Multimedia Systems Planning, Florida Department of Transportation by Frederic R. Harris, Inc. Tallahassee, Florida. September 1988.

13. Urban Transportation Planning Model Update Phase II. "Task C: Develop Standardized Distribution and Assignment Models." Prepared for the Florida Department of Transportation by COMSIS Corporation. Tallahassee, Florida. October 1981.

14. Nungesser, L.G. \& Ledbetter, N.P. Procedures for Estimating Park and Ride Demand in Large Texas Cities. Report No. FHWA/TX-87/24+339-7. Prepared by the Texas Transportation Institute, Texas A \& M University for the Transportation Planning Division, Texas State Department of Highways and Public Transportation. Springfield, Virginia: National Technical Information Service. February 1987.

15. Park and Ride Facilities Demand Estimate. I-95 System Maintenance of Traffic Program. WPI 86070-1498. Prepared for the Florida Department of Transportation by Frederic R. Harris, Inc. Fort Lauderdale, Florida. August 1987.

16. Simplified Aids for Transportation Analysis. Report No. UMTA-UPM-20-80-1. Office of Planning and Methods Support, Urban Mass Transportation Administration. Springfield, Virginia: National Technical Information Service. January 1980.

17. Pratt, R.H. \& Copple, J.N. Traveler Response to Transportation System Changes. DOTFH-11-9579. Prepared for the Federal Highway Administration by R.H. Pratt \& Co. Division, Barton-Aschman Associates, Inc. Washington, D.C.: U.S. Government Printing Office. July 1981.

18. Tampa Bay Regional Transportation Analysis Phase III. "Technical Report No. 1, Validation of the Tampa Bay Regional Planning Model Version 3.2." Planning Office, Florida Department of Transportation, District 7, Tampa, Florida. 1999.

19. 2020 Transportation Plan Update. Prepared by Tindale-Oliver and Associates for the Volusia County Metropolitan Planning Organization. Daytona Beach, Florida. 1996. 


\section{CHAPTER 6: ECONOMIC ANALYSIS AND PROJECT JUSTIFICATION}

This chapter provides direction for performing economic analyses of park-and-ride improvements, along with an example for demonstration purposes:

- outline for a justification report

- description of benefit, cost, and effectiveness measures

- framework for performing economic analyses

- example of economic analysis

The material presented in this chapter is an abridgment of similar material contained in Working Paper 4: Facility Analysis [1]. That document should be referenced for supporting research findings that are not contained in this chapter.

\section{THE JUSTIFICATION REPORT}

All proposals for park-and-ride projects must include a justification report which contains sufficient explanation and data to show a need and purpose. It should consider: benefit and cost impacts; compatibility with state and local plans; impacts on surrounding transportation systems; and how the proposed improvement will address identified need(s). Findings of these considerations should be applied using the following outline:

I. Introduction

Summarize the purpose, need, benefits, and costs of the project

II. Background

Present the context of the project in relation to the impact area, existing and future transportation systems, measures (if any) which have been implemented in an attempt to solve the stated need(s), and the response of users to similar local facilities.

III. Plans and Improvements

Describe how the proposed improvement is compatible with state and local plans. Also describe transportation improvements and conditions which may have a bearing on the analysis, such as other commuter parking facilities, highway expansion, and transit services.

IV. Locational Analysis (for construction on new right-of-way only)

Present site selection information, using criteria found in Chapter 3.

V. Demand Analysis

Present forecasts of utilization in the construction year and the planning year. (See Chapter 4 for relevant procedures.)

VI. Benefit/Cost Assessment

Describe benefits and costs for proposed improvement, measurable in monetary units.

VII. Optional Cost Effectiveness Assessment

Describe the impacts of proposed improvement in terms which cannot be quantified in monetary units. Cost-effectiveness measures are presented in terms of amount of improvement per dollar of cost.

VIII. Conclusions

Summarize the need and benefits of the proposed improvement.

BENEFIT, COST, AND EFFECTIVENESS MEASURES

This section presents a review of the measures relevant to the analysis of park-and-ride 
improvements. All monetary values stated in this section are in 1989 prices. (Adjustments for inflation can be made using Table 6-3.) Table 6-1 presents a listing of cost, benefit, and effectiveness measures which should be considered for inclusion in the justification report.

Table 6-1

Benefit, Cost, and Effectiveness Measures for Analysis of Park-And-Ride Improvements

\begin{tabular}{|c|c|c|c|}
\hline Improvement & Benefit Measure & Cost Measure & Effectiveness Measure \\
\hline HOV-Related Facility & $\begin{array}{l}\text { Travel time } \\
\text { Vehicle operation } \\
\text { Accidents }\end{array}$ & $\begin{array}{l}\text { Engineering } \\
\text { Construction } \\
\text { ROW } \\
\text { Maintenance }\end{array}$ & $\begin{array}{l}\text { Auto occupancy } \\
\text { Peak-hour highway LOS } \\
\text { VMT reduction } \\
\text { Air quality } \\
\text { Fuel savings }\end{array}$ \\
\hline Fixed-Guideway Facility & $\begin{array}{l}\text { Vehicle operation } \\
\text { Accidents } \\
\text { Travel time } \\
\text { Transit fares }\end{array}$ & $\begin{array}{l}\text { Engineering } \\
\text { Construction } \\
\text { ROW } \\
\text { Maintenance }\end{array}$ & $\begin{array}{l}\text { Transit ridership } \\
\text { Peak-hour highway LOS } \\
\text { VMT reduction } \\
\text { Air quality } \\
\text { Fuel savings }\end{array}$ \\
\hline Express Bus Facility & $\begin{array}{l}\text { Vehicle operation } \\
\text { Accidents } \\
\text { Travel time } \\
\text { Transit fares }\end{array}$ & $\begin{array}{l}\text { Engineering } \\
\text { Construction } \\
\text { Maintenance } \\
\text { Transit O\&M } \\
\text { Transit capital }\end{array}$ & $\begin{array}{l}\text { Transit ridership } \\
\text { Peak-hour highway LOS } \\
\text { VMT reduction } \\
\text { Air quality } \\
\text { Fuel savings }\end{array}$ \\
\hline Carpool-Only Facility & $\begin{array}{l}\text { Vehicle operation } \\
\text { Accident } \\
\text { Travel time }\end{array}$ & $\begin{array}{l}\text { Engineering } \\
\text { Construction } \\
\text { ROW } \\
\text { Maintenance }\end{array}$ & $\begin{array}{l}\text { Auto occupancy } \\
\text { VMT reduction } \\
\text { Peak-hours LOS } \\
\text { Air quality } \\
\text { Fuel savings }\end{array}$ \\
\hline Expansion on Adjacent ROW & $\begin{array}{l}\text { Vehicle operation } \\
\text { Accidents } \\
\text { Travel time }\end{array}$ & $\begin{array}{l}\text { Engineering } \\
\text { Construction } \\
\text { ROW } \\
\text { Maintenance }\end{array}$ & $\begin{array}{l}\text { Auto occupancy } \\
\text { VMT reduction } \\
\text { Peak-hour LOS } \\
\text { Air quality } \\
\text { Fuel savings }\end{array}$ \\
\hline Structure on Existing ROW & $\begin{array}{l}\text { Vehicle operation } \\
\text { Accidents } \\
\text { Travel time }\end{array}$ & $\begin{array}{l}\text { Engineering } \\
\text { Construction } \\
\text { ROW } \\
\text { Maintenance }\end{array}$ & $\begin{array}{l}\text { Auto occupancy } \\
\text { VMT reduction } \\
\text { Peak-hour LOS } \\
\text { Air quality } \\
\text { Fuel savings }\end{array}$ \\
\hline $\begin{array}{l}\text { Modification of Existing } \\
\text { Design }\end{array}$ & $\begin{array}{l}\text { Vehicle operation } \\
\text { Accidents } \\
\text { Travel time }\end{array}$ & $\begin{array}{l}\text { Engineering } \\
\text { Construction } \\
\text { ROW } \\
\text { Maintenance }\end{array}$ & $\begin{array}{l}\text { Auto occupancy } \\
\text { VMT reduction } \\
\text { Peak-hour LOS } \\
\text { Air quality } \\
\text { Fuel savings }\end{array}$ \\
\hline Joint Development & $\begin{array}{l}\text { Vehicle operation } \\
\text { Accidents } \\
\text { Travel time }\end{array}$ & $\begin{array}{l}\text { Engineering } \\
\text { Construction } \\
\text { Annual lease } \\
\text { Administration }\end{array}$ & $\begin{array}{l}\text { Auto occupancy } \\
\text { VMT reduction } \\
\text { Peak-hour LOS } \\
\text { Air quality } \\
\text { Fuel savings }\end{array}$ \\
\hline Provision of Transit Services & $\begin{array}{l}\text { Vehicle operation } \\
\text { Accidents } \\
\text { Travel time }\end{array}$ & $\begin{array}{l}\text { Transit capital } \\
\text { Transit O\&M }\end{array}$ & $\begin{array}{l}\text { Transit ridership } \\
\text { VMT reductions } \\
\text { Peak-hour LOS } \\
\text { Air quality } \\
\text { Fuel savings }\end{array}$ \\
\hline
\end{tabular}




\section{Benefit Measures}

Benefit measures are those things that make the improvement profitable or useful. These measures are expressed in monetary units, typically in terms of user savings.

Accidents: The cost of accidents is the loss of income associated with fatality and injury accidents, and the value of property damage related to property damage only accidents. Accident rates by type can be calculated on a VMT basis.

Transit Fares: Transit fares should be added to the user cost of travel. Fare schedules for the local transit agency should be referenced. Preliminary user cost estimates can be based on $\$ 1$ per person trip when using express bus and urban rail service, $\$ 2$ per person trip using commuter rail service, and $\$ 0.50$ to $\$ 0.75$ per person trip using local bus service.

Travel Time: This measure is the change in user travel time as a result of the improvement. (Computation of travel time impacts are presented in Chapter 5.) Travel time is converted to a dollar value through the use of a value-of-time factor. The value of travel time for the work trip purpose is appropriate for the analysis of park-and-ride improvements. A value of $\$ 5$ per hour is typically used in economic analyses of transportation improvements.

Vehicle

Operation: Vehicle operation costs are related to running speed, speed changes, roadway gradient, and degree of curvature of tangent roadways. Parking charges are also included in this category. Estimating these costs is only recommended for economic studies of HOV facilities. Procedures are contained in the AASHTO Benefit/Cost Manual [2]. Use of per-mile unit operating costs are more appropriate for analyzing other park-and-ride improvements. A value of 20 cents per vehicle mile is appropriate [8]. This value does not include capital, depreciation, or insurance, since these costs would continue to be incurred by the auto owner using the facility.

\section{Project Costs}

Project costs relate to design, construction, maintenance, and operation of the proposed transportation improvement(s). For carpool only park-and-ride facilities, project costs are only those associated with the facility. For an HOV facility, project costs include construction and operation of the HOV facility and park-and-ride lot. In addition, transit operating and maintenance (O\&M) costs are included when transit services are to be provided.

Annual

Lease: Legislation usually requires the state or local agency to enter into a lease agreement to operate a joint-use facility. These costs are insignificant, approximately $\$ 12$ per space per year.

Capital Cost: Capital cost is the sum of construction, engineering, right-of-way, and transit capital. 
Construction: Construction costs include: supervision, staking, inspection, and testing; facility elements such as earthwork, pavement, drainage, embankments, structures, and ramps; landscaping and erosion control; maintenance of traffic; and traffic control devices. The cost basis includes labor, materials, equipment, and contractor overhead and profit margin. The best source for these costs is the preliminary or final engineer's estimate. Unit construction costs can also be developed from historical experience.

The following unit construction costs can be used for preliminary estimates:

- Garage costs: $\$ 6,000$ per parking space [3]

- Surface lot costs: $\$ 2,000$ per parking space [4]

- HOV lanes: $\$ 1,000,000$ per lane mile [5]

- Direct-access ramps: $\$ 10,000,000$ per pair of ramps [6]

Engineering: Engineering costs include preliminary engineering, final design and construction plans, and preparation of specifications. There are associated costs for design concepts, preliminary layouts, land and aerial surveys, right-of-way appraisals, soils investigations, if required, environmental assessments, final design plans, and preparation of construction drawings, specifications, and bid documents. These costs will tend to be a higher percentage for HOV facilities and parking garages, while they will be zero for an improvement that consists solely of adding transit service. The development of these costs is best derived as a historical percentage of construction costs. This is typically 20 percent.

Maintenance: Maintenance costs include: routine and periodic upkeep such as patching, striping, painting, drainage clean-out, and landscaping; replacement of pavement, traffic control devices, fences, guardrails, etc. The cost of maintaining park-and-ride facilities is approximately $\$ 60$ per space per year.

Operations: Operation costs include utility charges, safety patrols, operation of signals, garbage removal, administration of lease agreements, and traffic surveillance. These costs may be lumped together with maintenance; however, they may be large enough to justify estimating them separately.

Right-of-

Way (ROW): Right-of-way costs include: purchase price; legal, title, and other fees related to transfer of ownership; administrative costs for negotiation, condemnation, or settlement; business, family, and utility relocation; and demolition. Another cost which can be considerable relates to environmental cleanup of hazardous waste. This may be large enough to eliminate a site or project from further consideration. Cost estimates for right-of-way should be obtained from the District Right-of-Way Office.

Transit

Capital: These costs are for investments in rolling stock. They may also include costs associated with benches and shelters at the park-and-ride facility, although it should be included as part of the construction costs (see above). 
Transit Operations

and Maintenance

(O\&M): $\quad$ Transit O\&M costs vary with the level, type, and speed of bus operation. They are typically related to vehicle miles generated by the system. They entail:

- Driver wages and fringe benefits

- Vehicle operation, including tires, gasoline, and lubricants

- Vehicle parts and repair

- Insurance, managerial and administrative labor

- Vehicle rental or depreciation

- The transit system=s contribution to roadway maintenance and operating costs

\section{Effectiveness Measures}

Effectiveness measures are benefits for which dollar values cannot be assigned. Typically these relate to quality of life attributes such as level of transportation service and environmental impacts. These measures are presented in the justification report to provide an accurate assessment of the full impacts of proposed improvement.

Air Quality: Impacts on air quality are measured in terms of annual tons of carbon monoxide, hydrocarbons, and nitrogen oxides B pollutants that are produced by automobiles and transit vehicles. In counties designated as nonattainment areas, improvement in air quality is usually seen as a local objective.

Auto

Occupancy: Increasing average vehicle occupancy is often a local objective, and is expressed in terms of persons per automobile. Increased occupancies result from shifting person trips from single-occupant vehicles to carpools and transit. Park-and-ride facilities will assist in meeting this goal. Other benefits from increased occupancy are decreased vehicle miles of travel (VMT), congestion levels, fuel consumption, and pollutant emissions. A value of 1.2 persons per vehicle is typically used in Florida.

Fuel Savings: This measure is presented in millions of gallons of fuel saved. Park-and-ride facilities can reduce fuel consumption through a reduction in vehicles on the road. Larger facilities serving limited-access highways might actually increase fuel consumption, because fuel efficiency decreases when speeds increase over $35 \mathrm{mph}$.

Level of Service

(LOS): Level of service is a qualitative assessment of the road user $=$ s perception of the quality of flow. This measure is represented by letter ratings ranging from $\mathrm{A}$ to $\mathrm{F}$, with A representing unrestrained travel and $F$ representing system failure. Improved level of service is nearly always a local objective, since it is part of Florida $=\mathrm{s}$ growth management legislation. LOS C or D is generally acceptable, but many urban facilities operate at $\mathrm{E}$ or $\mathrm{F}$. Park-and-ride facilities can have a measurable impact on LOS if they are relatively large and highly utilized. 
Transit

Ridership: This measure is presented on an annual basis. Increasing transit ridership is an objective of virtually every local transit plan, and is becoming more important as adding road capacity is becoming cost-prohibitive and often contrary to growth management. This objective is only relevant to park-and-ride improvements where transit service is planned.

VMT

Reduction: Reduction of vehicle miles of travel is an expected benefit of park-and-ride improvements, including HOV facilities, parking lots and garages, and transit service. It is normally expressed on an annual basis in units of one million vehicle miles. Reduced VMT is often a stated objective of the local transportation plan. VMT reduction has positive benefits, including reduced congestion levels, fuel consumption, and vehicle emissions.

\section{ECONOMIC ANALYSIS OF PARK-AND-RIDE IMPROVEMENTS}

The economic analysis of a park-and-ride improvement should follow a series of steps. The process contained in the AASHTO Red Book [2] has been adopted by the Department as the prescribed procedure for analyzing construction projects.

\section{Cost Updates}

Unit costs associated with users, construction, and operation should be updated to maintain consistency with the Department $=\mathrm{s}$ latest cost values. These unit costs should be updated whenever they change in real dollars. Adjusting these unit costs for inflation to a new time basis is a separate issue and is addressed as a study feature below.

\section{Study Features}

Critical features of the economic study include the discount rate, value of travel time, analysis period, study years, and the time basis in which all monetary amounts are stated.

Discount rates are used to compute present values of economic investment and user costs. A discount rate of 7 percent is currently employed for transportation projects.

As mentioned above, the economic value of time spent commuting is computed through the use of a value-of-time factor. The value of time for the work trip purpose is appropriate for the analysis of park-and-ride improvements, since the associated impacts are realized during commuting hours. The value of commuter travel time ranges from 20 to 40 percent of the commuter's income [7]. A value of \$5 (in 1989 prices) per hour is typically used in economic analyses of transportation improvements.

The selected analysis period for the study should be consistent with the economic life of the improvement. Different components of the improvement will have differing life cycles. Standard economic life values used by the Department include 60 years for right-of-way; 40 years for earthwork, drainage systems, and structures; and 20 years for pavements and base course. Life cycle lengths for transit vehicles can be assumed to be 15 years. Table 6-2 presents appropriate economic lives for park-and-ride improvements. 
Table 6-2

Economic Life Cycles for Park-and-Ride Improvements

\begin{tabular}{ll} 
Improvement & Life Cycle \\
\hline HOV-Related Facility & $20+$ years \\
Fixed Guideway Facility & $20+$ years \\
Express Bus Facility & 15 years \\
Isolated Facility & 20 years \\
Expansion on Adjacent ROW & 20 years \\
Structure on Existing ROW & 40 years \\
Modification of Existing Design & 15 years \\
Joint-Development & 5 years \\
Provision of Transit Services & 15 years
\end{tabular}

The selection of study years allows for the simplification of estimating the annual values of user benefits and project costs over the length of analysis period. Typically, two years are selected - the base year and some future year. Annual costs are then interpolated between the two study years. A 20 -year planning horizon is a traditional future study year. The future study year should be selected based on considerations of the economic life of the project and the available years of travel forecasts.

Table 6-3

Default Adjustment Factors for Inflation

\begin{tabular}{|c|c|}
\hline Number of Years & Adiustment Factor \\
\hline 1 & 1.0300 \\
\hline 2 & 1.0609 \\
\hline 3 & 1.0927 \\
\hline 4 & 1.1255 \\
\hline 5 & 1.1593 \\
\hline 6 & 1.1941 \\
\hline 7 & 1.2299 \\
\hline 8 & 1.2668 \\
\hline 9 & 1.3048 \\
\hline 10 & 1.3439 \\
\hline 11 & 1.3842 \\
\hline 12 & 1.4258 \\
\hline 13 & 1.4685 \\
\hline 14 & 1.5126 \\
\hline 15 & 1.5580 \\
\hline
\end{tabular}

\begin{tabular}{|c|c|}
\hline Number of Years & Adiustment Factor \\
\hline 16 & 1.6047 \\
\hline 17 & 1.6528 \\
\hline 18 & 1.7024 \\
\hline 19 & 1.7535 \\
\hline 20 & 1.8061 \\
\hline 21 & 1.8603 \\
\hline 22 & 1.9161 \\
\hline 23 & 1.9736 \\
\hline 24 & 2.0328 \\
\hline 25 & 2.0938 \\
\hline 26 & 2.1566 \\
\hline 27 & 2.2213 \\
\hline 28 & 2.2879 \\
\hline 29 & 2.3566 \\
\hline 30 & 2.4273 \\
\hline
\end{tabular}

What year is chosen as the time basis to state all dollar amounts is not a substantive issue as long as one is used. However, it may be natural to use the year in which the study is done as the time basis. Recommended adjustment procedures include use of either average or commodity-specific consumer and wholesale price indices to factor base unit rates to the new time basis. A default procedure may be used for preliminary analysis. Assuming an average rate of 3 percent as the inflationary factor, 
Table 6-3 gives the corresponding adjustment factor and the number of years between the year in which the original dollar amount is stated to the selected time basis. For example, to adjust dollar amounts in 1989 prices to dollars in 2000 prices, one would use the adjustment factor corresponding to 11 years (from 1989 to 2000 ), which is 1.3842 .

\section{Project Description and Costs}

The proposed improvement should be defined in sufficient detail to estimate project and user costs. Different analysis sections should be identified to estimate costs related to HOV facilities only. Sections should be defined by length, gradients, curvature, and speed change characteristics.

The length of the travel path between the park-and-ride facility and the major destination areas should be identified and sectioned for areas representing congested freeway, uncongested freeway, congested arterial, and uncongested arterial roadway. Chapter 5 presents methods for determining these classifications of roadways in computing facility impacts related to travel time, fuel consumption, and vehicle emissions.

\section{Transit Costs}

Transit costs are treated in two categories: capital costs and operations and maintenance (O\&M) costs. The level of transit service and related number of additional vehicles must be determined to derive these costs.

Capital costs relate to investments in fixed facilities including vehicles, benches, shelters, and route signs. Costs associated with HOV lane construction or physical improvements at the park-and-ride facility are included in the project costs discussed in the preceding section.

O\&M costs include driver wages and fringe benefits, vehicle operation, and labor and parts associated with bus maintenance. O\&M costs may be estimated by multiplying the amount of revenue vehicle miles serving the park-and-ride lot by the local average O\&M cost per revenue vehicle mile. A statewide average may be used as the default.

\section{User Benefits}

User benefits consist of the annual savings in travel time, vehicle operation, accident, parking, and transit fare costs which users realize through the implementation of an improvement. Data required for these computations are estimates of reduction in VMT and travel time and savings in parking and transit fare costs. Chapters 4 and 5 present methods for computing these data. Total annual user benefits are developed by multiplying the appropriate cost factors by the estimated reduction in VMT and person hours of travel. Table 6-4 presents default values of the cost factors which may be used in lieu of available local data. This calculation is represented by the following formula:

$$
\begin{aligned}
& \mathrm{UB}=\mathrm{C}_{\mathrm{H}} * \mathrm{PHT}+\mathrm{C}_{\mathrm{O}} * \mathrm{VMT}+\mathrm{C}_{\mathrm{A}} * \mathrm{VMT}+\mathrm{TF} \\
& \text { where: } \\
& \begin{aligned}
\mathrm{UB}= & \text { User Benefits } \\
\mathrm{C}_{\mathrm{H}} & =\text { Cost factor for person hours of travel (dollars per PHT) } \\
\mathrm{C}_{\mathrm{O}} & =\text { Cost factor for vehicle operations (dollars per VMT) } \\
\mathrm{C}_{\mathrm{A}} & =\text { Cost factor for accidents (dollars per VMT) } \\
\mathrm{PHT} & =\text { Reduction in person hours of travel (hours) } \\
\mathrm{VMT} & =\text { Reduction in vehicle miles of travel (miles) }
\end{aligned}
\end{aligned}
$$


$\mathrm{TF} \quad=$ Savings in transit fare (dollars)

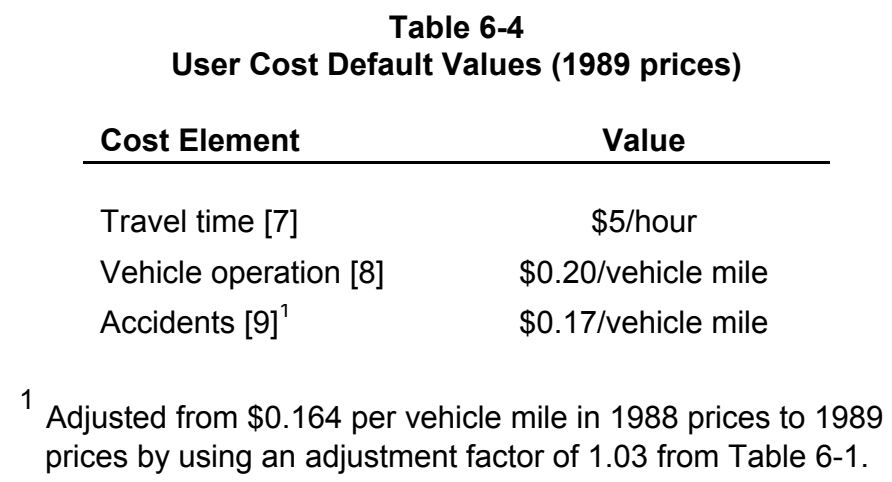

\section{Residual Value}

Residual value is the economic value of an improvement at the end of the analysis period. To compute residual value is to take the full cost of the land, subtract the disposal costs, and add the proportion of the remaining useful life of structures and earthwork times their cost.

\section{Present Values and Economic Evaluation}

The Department procedure for this final step is to bring all costs to an annual basis and compute a benefit/cost ratio. A capital recovery factor (CR) based on the discount rate is used to convert the present worth of construction and equipment to annual basis. An appropriate sinking fund factor (SF) based on the discount rate is applied to convert future residual values to an annual basis. Equations for these factors are as follows:

$$
\begin{aligned}
& \mathrm{CR}=\mathrm{i}(1+\mathrm{i})^{\mathrm{n}} /\left[(1+\mathrm{i})^{\mathrm{n}}-1\right] \\
& \mathrm{SF}=\mathrm{i} /\left[(1+\mathrm{i})^{\mathrm{n}}-1\right] \\
& \text { where: } \\
& \mathrm{CR}= \\
& \mathrm{SF} \quad \text { Capital recovery factor } \\
& \mathrm{i} \quad \text { Sinking fund factor } \\
& \mathrm{n} \quad=\text { Discount rate } \\
&
\end{aligned}
$$

The annual project cost is computed as follows:

$$
\begin{aligned}
& \mathrm{PC}=\mathrm{O} \& \mathrm{M}+\mathrm{CC} * \mathrm{CR}+\mathrm{RC} * \mathrm{SF} \\
& \text { where: } \\
& \mathrm{PC}=\begin{array}{l}
\text { Annualized total project cost } \\
\mathrm{O} \& \mathrm{M}= \\
\text { Total annual operation and maintenance costs including transit, highway, and } \\
\text { park-and-ride facility costs }
\end{array} \\
& \mathrm{CC}=\begin{array}{c}
\text { Total capital costs including fixed facilities and rolling stock } \\
\mathrm{RC}= \\
\text { Residual value for all salvageable property and rolling stock at the end of the } \\
\text { analysis period }
\end{array} \\
& \mathrm{CR}=\begin{array}{c}
\text { Capital recovery factor }
\end{array}
\end{aligned}
$$


$\mathrm{SF} \quad=$ Sinking fund factor

The following formula is used to compute the benefit/cost ratio for an improvement:

$$
\begin{aligned}
& \mathrm{BC}=\mathrm{UB} / \mathrm{PC} \\
& \text { where: } \\
& \mathrm{BC}=\text { Benefit/cost ratio for the improvement } \\
& \mathrm{UB}=\text { Annual user benefits of the improvement } \\
& \mathrm{PC}=\text { Annualized project cost of the improvement }
\end{aligned}
$$

A BC value greater than one indicates economic feasibility of a project.

\section{AN EXAMPLE OF ECONOMIC ANALYSIS}

\section{Introduction}

The purpose of this example is to illustrate the method presented above with a consistent set of realistic numbers. The objective is to compute the benefit-cost ratio of a single planned park-andride lot compared to a do-nothing alternative. This example is adopted from the 1993 Dade County Park and Ride Lot Plan, prepared by Frederic R. Harris, Inc. for District 6, Florida Department of Transportation, and based on the Florida Department of Transportation's Park and Ride Manual. The specific numbers in the example are those for a planned park and ride lot located at $87^{\text {th }}$ Avenue and SW $22^{\text {nd }}$ Street. The rest of the section is structured into six steps: (1) study features; (2) cost factors; (3) project description (4) user benefits; (5) project costs; and (6) results.

\section{Study Features}

The study features provide the boundaries within which an economic analysis of a proposed park and ride lot would be conducted. Features for the current example are summarized below in Table 6-5. The year 1993 is chosen as the time basis for dollar amounts because that was the year of the original study from which this example is based. 
Table 6-5

Example Study Features

\begin{tabular}{|c|c|c|}
\hline Study Feature & Value & Comments \\
\hline Analysis period & $1990-2010$ & \\
\hline \multicolumn{3}{|l|}{ Study years } \\
\hline Construction costs & 1990 & Beginning of the analysis period \\
\hline Annual user benefits & 2000 & Middle of the analysis period \\
\hline Year of constant dollars & 1993 & $\begin{array}{l}\text { All monetary values must be measured in } \\
1993 \text { prices. }\end{array}$ \\
\hline Annual rate of inflation & 3 percent & $\begin{array}{l}\text { Used to convert monetary values into } 1993 \\
\text { prices. }\end{array}$ \\
\hline Economic life $(n)$ & 20 years & $\begin{array}{l}\text { Does not have to be the same as the analysis } \\
\text { period length. }\end{array}$ \\
\hline Discount rate (i) & 7 percent & Used in the source. \\
\hline Capital recovery factor $(\mathrm{CR})$ & 0.0944 & $i(1+i)^{n} /\left[(1+i)^{n}-1\right]$ \\
\hline Sinking fund factor (SF) & 0.0244 & $\mathrm{i} /\left[(1+\mathrm{i})^{\mathrm{n}}-1\right]$ \\
\hline Annual working days & 233 & \\
\hline
\end{tabular}

\section{Cost Factors}

There are three sets of unit costs: capital; operation and maintenance; and users. Some of these are from the original study, including the unit costs for signs, land, and transit rolling stock. Others are the default values in this chapter, which have been converted from 1989 to 1993 prices. Using Table 6-3, the number of years for adjustment is 4 and the corresponding adjustment factor is 1.1255 .

\section{Capital:}

Construction cost per space $=\$ 2,000 * 1.1255=\$ 2,251$

Signage cost per lot (arterial) $=\$ 3,489$

Land cost per square foot $=\$ 14.53$

Transit rolling stocks $\quad=\$ 208,218$ per bus

Operation and Maintenance:

Park and ride lot $\quad=\$ 60 * 1.1255=\$ 67.53$ per space

Users:

Value of time savings $\quad=\$ 5.00 * 1.1255=\$ 5.63$ per hour

Vehicle operation $\quad=\$ 0.20 * 1.1255=\$ 0.23$ per mile

Accidents $\quad=\$ 0.17 * 1.1255=\$ 0.19$ per mile

Transit fare $\quad=\$ 1.00 * 1.1255=\$ 1.13$ per ride 


\section{Project Description}

In addition to unit costs, project costs and user benefits also depend on the size of the park-and-ride lot, associated transit services, and its impacts in terms of reduction in VMT and person hours of travel by automobile users. These are summarized in Table 6-6.

Table 6-6

Example Project Description

\begin{tabular}{|c|c|c|}
\hline Characteristics & Values & Comments \\
\hline $\begin{array}{l}\text { Size } \\
\text { Demand } \\
\text { Land } \\
\end{array}$ & $\begin{array}{l}200 \text { spaces } \\
1.6 \text { acres } \\
\end{array}$ & Rounded from 174 \\
\hline $\begin{array}{l}\text { Transit Service } \\
\text { Distance to CBD } \\
\text { Number of buses } \\
\text { Frequency } \\
\text { Daily span } \\
\text { Average O\&M cost } \\
\text { Annual ridership } \\
\text { Annual revenue miles }\end{array}$ & $\begin{array}{l}15 \text { miles round trip } \\
2 \\
4 \text { per hour } \\
5 \text { hours } \\
\$ 6.51 \text { per revenue mile } \\
45,726 \text { boardings } \\
69,900 \text { miles }\end{array}$ & $\begin{array}{l}\text { New } \\
\text { In } 1993 \text { prices } \\
4 * 5 * 233 * 15=69,900\end{array}$ \\
\hline $\begin{array}{l}\text { Impacts } \\
\text { Vehicle miles of travel } \\
\text { Person hours }\end{array}$ & $\begin{array}{l}580,590 \text { miles } \\
7,144 \text { hours }\end{array}$ & \\
\hline
\end{tabular}

\section{User Benefits}

User benefits are first computed by components and then totaled to get an annual figure for year 2000 .

User benefits from time savings:

$$
\begin{aligned}
\mathrm{C}_{\mathrm{H}} * \mathrm{PHT} & =\text { value of time savings } * \text { reduction in person hours of travel } \\
& =\$ 5.63 * 7,144 \\
& =\$ 40,221
\end{aligned}
$$

User benefits from savings in vehicle operation:

$$
\begin{aligned}
\mathrm{C}_{\mathrm{O}} * \mathrm{VMT}= & \text { unit cost of vehicle operation * reduction in vehicle miles of travel } \\
& =\$ 0.23 * 580,590 \\
& =\$ 133,536
\end{aligned}
$$

User benefits from reduction in accidents:

$$
\begin{aligned}
\mathrm{C}_{\mathrm{A}} * \mathrm{VMT}= & \text { unit cost of accidents * reduction in vehicle miles of travel } \\
& =\$ 0.19 * 580,590 \\
& =\$ 110,312
\end{aligned}
$$

User benefits from savings in transit fare: 
$\mathrm{TF}$

$$
\begin{aligned}
& =- \text { fare per ride } * \text { annual ridership } \\
& =-\$ 1.13 * 47,726 \\
& =-\$ 53,930
\end{aligned}
$$

Annual total user benefits:

$$
\begin{aligned}
\mathrm{UB} \quad= & \mathrm{C}_{\mathrm{H}} * \mathrm{PHT}+\mathrm{C}_{\mathrm{O}} * \mathrm{VMT}+\mathrm{C}_{\mathrm{A}} * \mathrm{VMT}+\mathrm{TF} \\
& =\$ 40,221+\$ 133,536+\$ 110,312-\$ 53,930 \\
& =\$ 230,139
\end{aligned}
$$

\section{Project Costs}

Annualized project costs include several components: annual operation and maintenance for both the park-and-ride lot and related transit services, annualized capital costs for both transit rolling stock and the construction of the park-and-ride lot, and annualized residual value of the park-and-ride lot at the end of the analysis period

Annual Operation and Maintenance

Park-and-ride lot

$$
\begin{aligned}
\mathrm{OM}_{\mathrm{P}} & \text { unit cost per space } * \text { number of spaces } \\
& =67.53 * 200 \\
& =\$ 13,506
\end{aligned}
$$

Transit service

$\mathrm{OM}_{\mathrm{T}} \quad=$ unit cost per mile * number of revenue miles

$=\$ 6.51 * 69,900$

$=\$ 455,049$.

Total Operation and Maintenance Costs

$$
\begin{aligned}
\mathrm{OM} & =\mathrm{OM}_{\mathrm{P}}+\mathrm{OM}_{\mathrm{T}} \\
& =\$ 468,555 .
\end{aligned}
$$

\section{Capital Costs}

Park-and-ride lot

$$
\begin{aligned}
\text { Construction } & =\text { unit cost per space } * \text { number of spaces } \\
& =\$ 2,251 * 200 \\
& =\$ 450,200 .
\end{aligned}
$$

Signage $\quad=\$ 3,489$.

$$
\begin{aligned}
\text { Engineering } & =0.20 * \text { construction cost (i.e., } 20 \% \text { of construction cost) } \\
& =0.20 * \$ 450,200 \\
& =\$ 90,040 .
\end{aligned}
$$

Land $\quad=$ unit cost per square foot $*$ (number of acres * square feet per acre)

$$
=\$ 14.53 *(1.6 * 43,560)
$$$$
=\$ 1,012,683 \text {. }
$$ 
Transit service

Rolling stock $=$ unit cost per bus * number of buses

$=\$ 208,218 * 2$

$=\$ 416,436$.

Total capital cost

$\mathrm{CC}$

$$
\begin{aligned}
= & \text { Construction cost }+ \text { signage cost }+ \text { engineering cost }+ \text { land cost }+ \text { transit } \\
& \text { rolling stock } \\
= & \$ 450,200+\$ 3,489+\$ 90,040+\$ 1,012,683+\$ 416,436 \\
= & \$ 1,972,848
\end{aligned}
$$

Residual Value

Since the duration of the analysis period is the same as the assumed life cycle of the park-andride lot, the residual value would be just that of the land. Assuming no appreciation, it is:

RC $\quad=$ Land cost

$=\$ 1,012,683$.

Annualized Project Cost

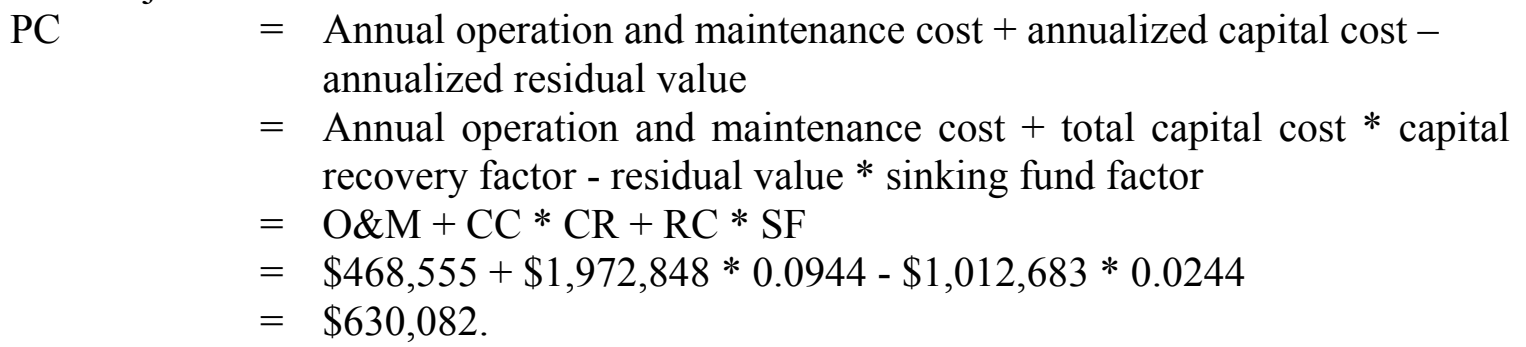

\section{Results}

The benefit-cost ratio of the proposed park-and-ride lot is:

$$
\begin{aligned}
\mathrm{BC} & =\mathrm{UB} / \mathrm{PC} \\
& =\$ \text { Annual user benefits / annualized project costs } \\
& =0.37
\end{aligned}
$$

Implementation of this proposed park-and-ride lot is not economically justified.

Note: This example does not include cost effectiveness measures. 


\section{References}

1. State Park and Ride Lot Program. Working Paper 4: Facility Analysis. Prepared for the Office of Public Transportation, Florida Department of Transportation, by Frederic R Harris, Inc., Tallahassee, Florida, October 1989.

2. A Manual on User Benefit Analysis of Highway and Bus-Transit Improvements. Washington, D.C.: American Association of State Highway and Transportation Officials, 1977.

3. Metro-Dade Transit Agency. Dadeland North Metrorail Parking Garage Project Justification. Miami, Florida, June 1987.

4. SR 94 Urban Corridor PTO Conceptual Design Study, Final Report. Prepared for the District VI Public Transportation Office, Florida Department of Transportation, by Frederic R. Harris, Inc. (formerly PRC Engineering, Inc.), Miami, Florida, 1985.

5. District VI Estimates, Florida Department of Transportation. Average Cost Per Mile for Roadway Construction, Miami, Florida, 1988.

6. Justification Report Interstate 95 From I-195 to SR 808 in Dade, Broward and Palm Beach Counties. Compiled by the Division of Transportation Planning, Florida Department of Transportation, Tallahassee, Florida, July 1978.

7. Stopher, P.R. Derivation of Values of Time from Travel Demand Models. Transportation Research Record 587, Washington, D.C.: Transportation Research Board, 1975.

8. Interchange Approval I-75 Corridor Study. Prepared for the Office of Highway Planning and Statistics, Florida Department of Transportation by Harland Bartholomew \& Associates, Inc. and lunter/RS\&H, Inc., Tallahassee, Florida (December 1988).

9. Small, K.A. Urban Transportation, Chapter 46, in Handbook of Regional and Urban Economics, p.1965, Elsevier Science, 1999. 